Portland State University

PDXScholar

3-6-1990

\title{
The Effect of Plant Growth Regulators on the Growth of Closterium moniliferum
}

Cynthia Lehua Warnock Christensen

Portland State University

Follow this and additional works at: https://pdxscholar.library.pdx.edu/open_access_etds

Part of the Biology Commons, and the Plant Sciences Commons

Let us know how access to this document benefits you.

\section{Recommended Citation}

Christensen, Cynthia Lehua Warnock, "The Effect of Plant Growth Regulators on the Growth of Closterium moniliferum" (1990). Dissertations and Theses. Paper 3968.

https://doi.org/10.15760/etd.5852

This Thesis is brought to you for free and open access. It has been accepted for inclusion in Dissertations and Theses by an authorized administrator of PDXScholar. Please contact us if we can make this document more accessible: pdxscholar@pdx.edu. 
AN ABSTRACT OF THE THESIS OF Cynthia Lehua Warnock Christensen for the Master of Science in Biology presented March 6, 1990.

Title: The Effect of Plant Growth Regulators on the Growth of Closterium moniliferum.

APPROVED BY THE MEMBERS OF THE THESIS COMMITTEE:

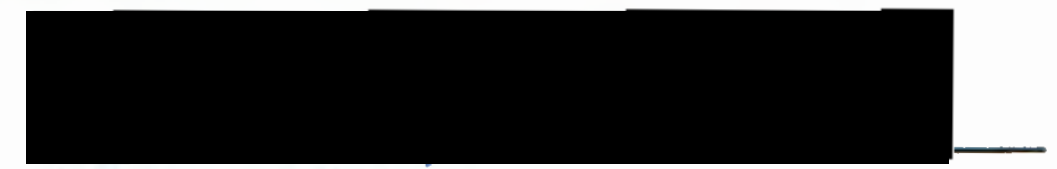

B. E. Lippert, Chairperson

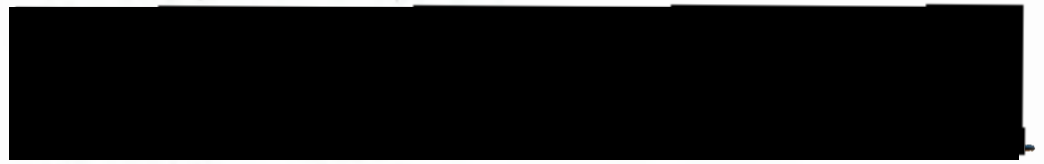

Richard Sandstrom

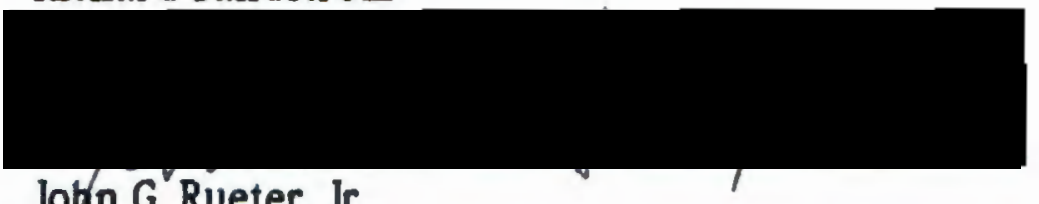

Joph G. Rueter, Jr.

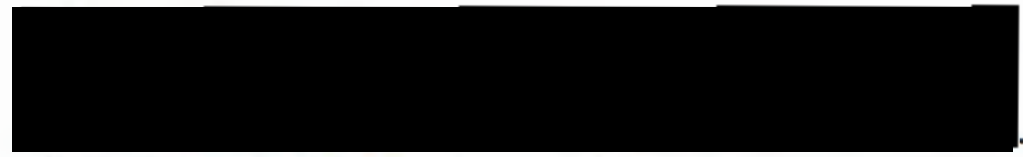

Colin G. Dunkeld

Physiologic responses to Gibberellic Acid (GA), 1-Naphthalene Acetic Acid (NAA), Benzylaminopurine (BAP), and Abscisic Acid (ABA), suggest that Closterium moniliferum has the ability to utilize these plant growth factors. The growth promoters NAA and GA both increased growth when added to the media. The cell division regulator BAP (a synthetic cytokinin), also had a promotive effect on growth. Abscisic acid was found to be inhibitive to growth. 
THE BFPECT OF PLANT GROWTH REGULATORS ON THE GROWTH OF CLOSTERIUN MONLIFERUW

\author{
by \\ CYNTHIA LEHUA WARNOCK CHRISTENSEN
}

A thesis submitted in partial fulfillment of the requirements for the degree of

MASTBR OP SCIBNCE

in

BIOLOGY

Portland State University

1990 


\section{TO THE OFFICE OF GRADUATE STUDIES:}

The members of the Committee approve the thesis of Cynthia Lehua Warnock Christensen presented March 6, 1990.
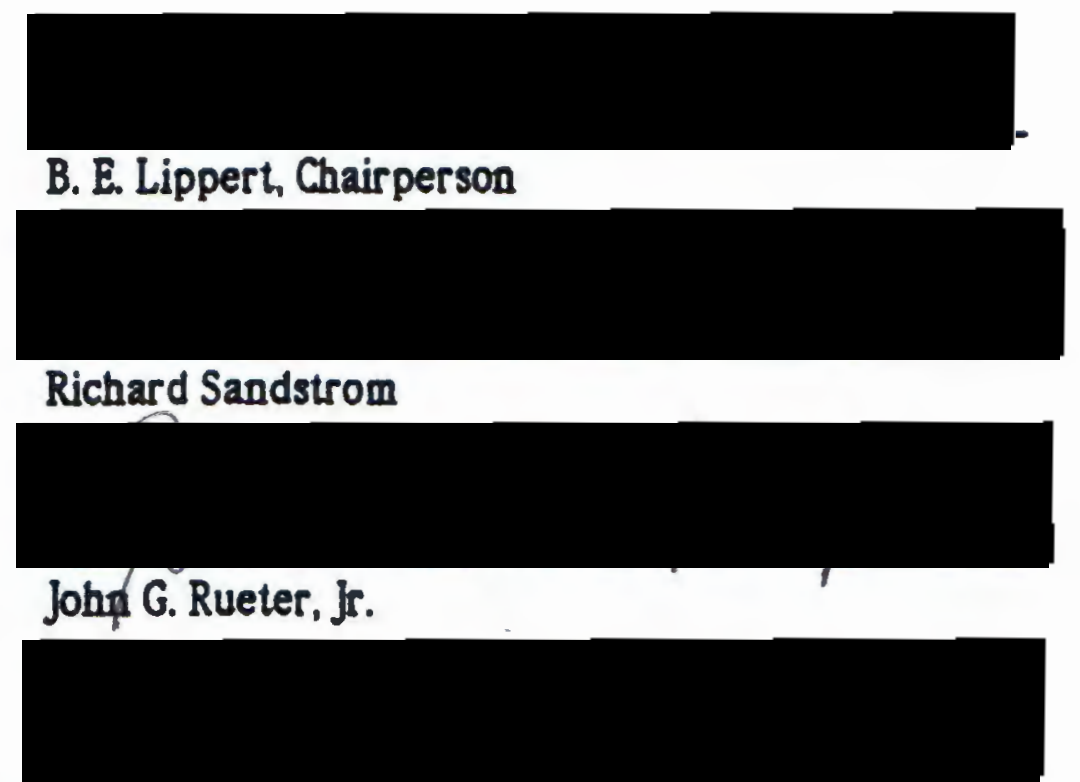

Colin G. Dunkeld

APPROVED

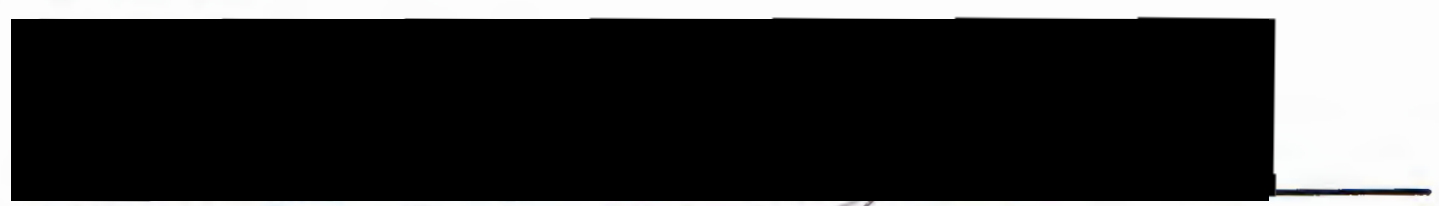

W. Herman Taylor, Head, Biology Department

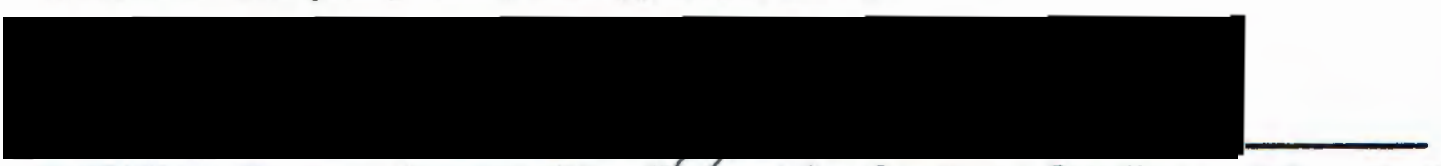

C. William Savery, Interim Vice Provost for Graduate Studies and Research 


\section{DEDICATION}

I dedicate this thesis to my daughter Celene, who I hope will develop my lifelong love of learning and exploring new places. 


\section{ACKNOWLEDGMENTS}

I wish to thank Rick Sandstrom for all of his help, ideas, and use of his lab; Ed Lippert for getting me interested in algae and plants; and Janet Cruden for giving me the inspiration to continue when the going got tough.

Most of all I wish to thank my husband for his patience and my daughter who has been waiting for Mommy to read to her. 
TABLE OF CONTENTS

PAGE

DEDICATION _ . . $\ldots \ldots \ldots$

ACKNOWLEDGEMENTS _... . . . . . . . . . .

LIST OF TABLES

LIST OF FIGURES $\ldots \ldots \ldots$

viii

CHAPTER

I INTRODUCTION $\ldots \ldots \ldots$

Vascular Plant Growth _........

Control of Plant Growth _.......

Eucaryotic Algal Growth _. . . . . .

Control of Algal Growth .........

Placoderm Desmids - - - - - - -

Statement of Research Goals _.......

II MATERIALS AND METHODS _ . . . . . .

The Organism $\ldots \ldots \ldots$

Preparation of the Medium _......

Environmental Conditions _....... 
Preparation of Glassware

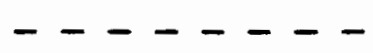

38

pH Measurement

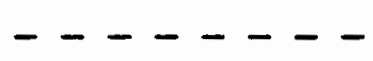

38

Photography

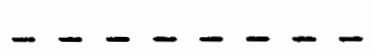

39

Monitoring of Cell Growth _ _ _ _ _

Statistical Treatment of Data _ $\ldots \ldots$

III RESULTS $\ldots \ldots \ldots$

Growth Promoters

$---\cdots$

Cell Division Factors

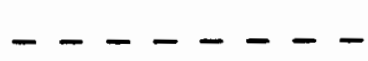

Growth Inhibitors

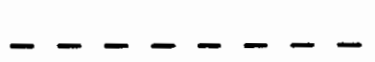

DISCUSSION

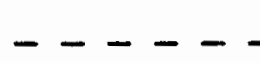

48

V

SUMMARY

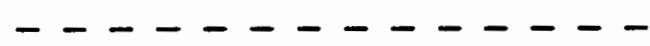




\section{LIST OF TABLES}

TABLE

PAGE

I

Recipe for Ichimura's Growth Media _ . . -

33

II

Summary of the effects of GA, NAA, and BAP

on Growth

- - - -

III

The Effect of ABA on Growth

45 
LIST OF FIGURES

FIGURE

PAGE

1. The Chemical Structure of Gibberellic Acid (GA3) - -

2. The Chemical Structure of an Isoprene Unit _...

3. The Concept of the Cell Cycle

4. The Chemical Structures of IAA and NAA _...-

5. The Chemical Structures of BAP and Kinetin _...

6. The Chemical Structure of Abscisic Acid _...

7. The Chemical Structure of Lunularic Acid _...-

8. Photomicrograph of Mature Cells Strain 49E Closterium moniliferum _.............

9. Cell Division-- Closterium Type _... . . -

10. Conjugation in Closterium the C. moniliferum-ehrenbergï Type _...........

11. Photograph of Algal Culture Room and of an Experiment in Progress _.............

12. $\approx$ Control versus GA Concentrations _.....

13. * Control versus NAA Concentrations _ . . . - 
14. * Control versus BAP Concentrations _ - - -

15. * Control versus ABA Concentrations _ - 


\section{CHAPTER I}

\section{INTRODUCTION}

\section{VASCULAR PLANT GROWTH}

Plant growth is a very complex process. Simply defined it can be understood as a permanent increase in size. This increase can come from an increase in cell volume, an increase in cell number or a combination of these two factors.

Autotrophic plants need light, water, minerals and $\mathrm{CO}_{2}$ for growth, reproduction and maintenance of life. When these conditions are right, a seed can germinate and the embryo within can grow and differentiate into the many specialized tissues of a mature vascular plant.

There are many methods used to measure growth. The most common methods involve the measurement of fresh and/or dry weight. Fresh weight is a variable quantity that is dependent upon the water content of vegetation at the time of harvest. Dry weight is determined by drying the freshly harvested plant for 24 to 48 hours at 70 to $80^{\circ} \mathrm{C}$ (Salisbury and Ross, 1985). Dry weight gives a more accurate estimate of the amount of carbon and minerals procured by the plants. While both fresh and dry weight measurements are well established and extensively used methods there are problems arising from their application. Fresh and dry weight measures require destruction of the vegetation under investigation and 
direct comparison of reported fresh weights in the literature is difficult because of variation in moisture content.

\section{CONTROL OF PLANT GROWTH}

Growth is ultimately controlled by a plant's genetic makeup. However, external environmental factors and plant growth factors are intimately involved. Interactions occur among these components as a plant monitors and responds to changes in its internal and external environment. These mechanisms serve to direct their growth toward more favorable conditions of light, nutrients and water.

\section{Genetic Control}

As stated above the plant's genome ultimately controls everything, from how it reproduces to the environmental extremes it can withstand. For example, the different metabolic pathways used to fix carbon are genetically encoded which predispose particular plants to out compete others in a given environment. Size is also another factor controlled by the genome of a plant. Dwarfing is usually caused by a single gene mutation which interferes with the enzymes needed for gibberellin (a plant growth factor necessary for "normal" height) synthesis (Salisbury and Ross, 1985).

\section{Environmental Control}

Light, water, minerals and temperature all play important roles in the growth and development of plants. Light and temperature are usually the driving forces or the activators of certain types of development which directly or indirectly influence plant growth. Light and temperature will be 
the focus of the present discussion regarding growth controlling factors.

Light can be promotive or inhibitive to growth. Chlorophyll production. leaf expansion, and root development are just a few of the growth processes promoted by light (Salisbury and Ross, 1985). Light can also play an inhibitory role as in the case of inhibiting stem elongation (Salisbury and Ross, 1985).

Light plays a major role in photosynthesis by suppling the energy to split water and drive the photosynthetic reactions. Plants have different mechanisms to maximize photosynthesis. They achieve this by regulating the density of chloroplasts and the density of photosynthetic units. Light can also affect chloroplast arrangement through phototaxis of the plastids (Salisbury and Ross, 1985). Some plants actually respond phototactically. This allows them to track the sun, thereby maintaining maximum exposure of the leaf surface.

Light regulates growth and development in plants through phytochrome responses. This is the main pigment found in plants that senses light signals used in the control of plant development. Phytochrome is a pigment that occurs in active and inactive forms, each having a different absorption spectrum. The inactive form $\left(\mathrm{Pr}_{\mathrm{r}}\right)$ has an absorption maximum at $660 \mathrm{~nm}$. This form is activated by illumination with red light (660 $\mathrm{nm}$ ) and is converted into (Pfr) which absorbs light at $730 \mathrm{~nm}$. Pfr can in turn be converted to Pr by illumination with $730 \mathrm{~nm}$ light. These reactions can continue ad infinitum, but is always the final light exposure that controls the physiological response of the plant (Goodwin and Mercer, 1985).

Phytochrome is involved at all levels of plant development. Examples 
of this are its influence on seed germination, dormancy, and vegetative growth. Evidence that the supplementation of various plant growth factors apparently substitutes for the light requirement indicates that there is probably some relationship between phytochrome and plant hormones (Salisbury and Ross, 1985). Additionally phytochrome is responsible for monitoring changes in photoperiod which may signal processes such as bud dormancy and flowering (Salisbury and Ross, 1985).

All plants have a temperature range wherein growth can occur. Too much variation in the temperature can result in cessation of growth or death of the plant. Moreover, all forms of vegetation have an optimum temperature range within which growth can occur at a maximal rate. Temperature influences seed germination through stratification, the onset and breaking of dormancy in perennial plants, and flower initiation through vernalization (Salisbury and Ross, 1985). These developmental responses are also influenced by the complex interactions of light, photoperiod and available moisture (Salisbury and Ross, 1985).

\section{Chemical Control}

Many substances will affect plant growth; but, this discussion of chemicals will be limited to plant hormones which play a major role in controlling growth and development. The plant hormones can be divided into three categories: growth promoters, cell division factors and growth inhibitors. The following discussion will describe the various hormones and what is known of their properties and function. 
Growth Promoters. The following section will discuss the promotive affect of gibberellins and auxins.

a. Gibberellins. Gibberellins (GA) are a group of hormones that are defined by their chemical structure and not by their biological activity. Over 70 forms are known (Davies, in Press). Gibberellins were named from the fungus Gibberella fujikuroi which caused the rice plants it infected to grow tall, spindly and to topple (Goodwin and Mercer, 1985). The initial gibberellins were isolated from this fungus. Gibberellic acid or GA3 was a predominant component (Davies, in Press). Figure 1 shows the structure of GA3.

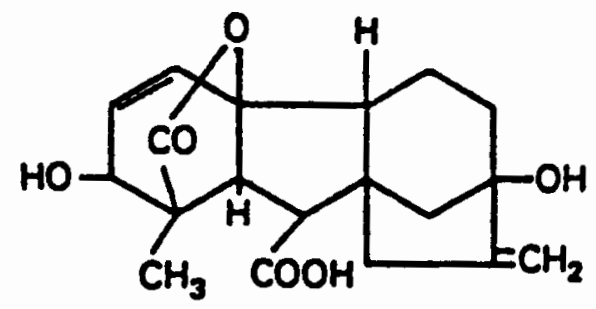

Eigure 1. The chemical structure of gibberellic acid (GA3).

Gibberellins are terpenoids made up of five carbon building blocks (isoprene units derived from the mevalonic acid pathway--see Figure 2). joined head to tail. Gibberellins have a basic structure containing 20 carbons formed from 4 isoprenoid units (Davies, in Press). Most gibberellins are inactive precursors or metabolites of bioactive gibberellins.

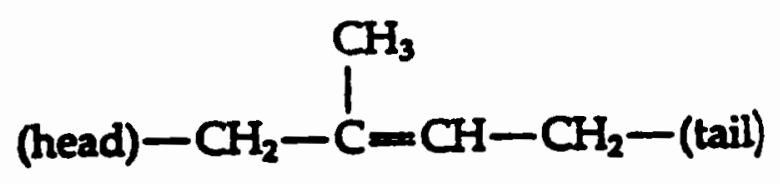

Eigure 2. The chemical structure of an isoprene unit. 
These inactive metabolites provide a means to get rid of a highly biologically-active compound (Davies, in Press).

The main effect of gibberellins is that they are responsible for tallness in plants. This is achieved by increasing cell number and elongation in stems (Davies, in Press). They are a group of hormones whose synthesis is under direct genetic control. Most dwarf plants are dwarfs because of mutations to genes that effect the biosynthesis of gibberellins. If $\mathrm{GA} 3$ is added to a dwarf species the plant will usually attain the height of its "normal" counterpart (Salisbury and Ross, 1985). The first gibberellins applied to dwarf plants were derived from fungi. It was the remarkable response of these dwarf plants that led investigators to search for naturally occurring gibberellins in vascular plants.

Gibberellins can be synthesized anywhere in the plant (Salisbury and Ross, 1985). The highest levels of gibberellins occur in seeds; but, the amounts differ between the various tissues (Davies, in Press). Lower concentrations of $\mathrm{GA}$ are found in the vegetative tissues of plants. Gibberellins appear to be synthesized and concentrated in young leaves. buds and upper stems (Davies, in press).

Historically, bioassays were the only method available to study compounds with hormone-like responses. Today many standard assays are used, depending on the hormone under investigation. However, the activity of gibberellins and gibberellin-like compounds can only be determined by bioassay. Three major bioassays are used for gibberellins: the lettuce hypocotyl elongation bioassay; the dwarf rice/microdrop bioassay; and detection of alpha-amylase production in germinating cereal grains (Davies, in Press). These bioassays are sensitive in a range of $0.1 \mu \mathrm{g} / 1$ to $100 \mu \mathrm{g} / 1$ 
(Davies, in Press).

Gibberellins will produce stem elongation in most dwarf plants which normally lack bioactive gibberellins or contain only small amounts of this active substance (Davies, in Press). Studies comparing the genetic makeup of tall and dwarf varieties have revealed mutations on genes in the dwarf variety that inhibit gibberellin synthesis (Davies, in Press).

Little is known about the control of stem elongation. It is hypothesized that GA affects calcium levels in the cell wall and calcium is involved in reducing cell wall extensibility (Davies, in Press). Increased cell division occurs in the shoot apex, (a meristematic region) by the shortening of the $\mathrm{S}$ phase and the stimulation of cells in Gl to enter the S phase (Salisbury and Ross, 1985). Figure 3 explains the cell cycle, but the fine regulation of it has not yet been worked out.

Gibberellins also stimulate the production of alpha-amylase in germinating cereal grains (Goodwin and Mercer. 1985). Gibberellin levels increase just as barley seeds begin to germinate. Alpha-amylase is needed to digest the stored starch and supply the developing embryo with energy. Alpha-amylase is newly synthesized in response to gibberellin and all evidence now indicates that gibberellin enhances the transcription of the alpha-amylase gene (Davies, in Press).

b. Auxins: IAA, NAA, and others. Auxins are a group of compounds, both natural and synthetic, that stimulate cell elongation in coleoptiles and many stems (Salisbury and Ross, 1985). Auxins usually regulate phototropism, which is a bending of a plant toward the strongest light (Stout, in Press). The primary auxin in vascular plants is indole-3-acetic 


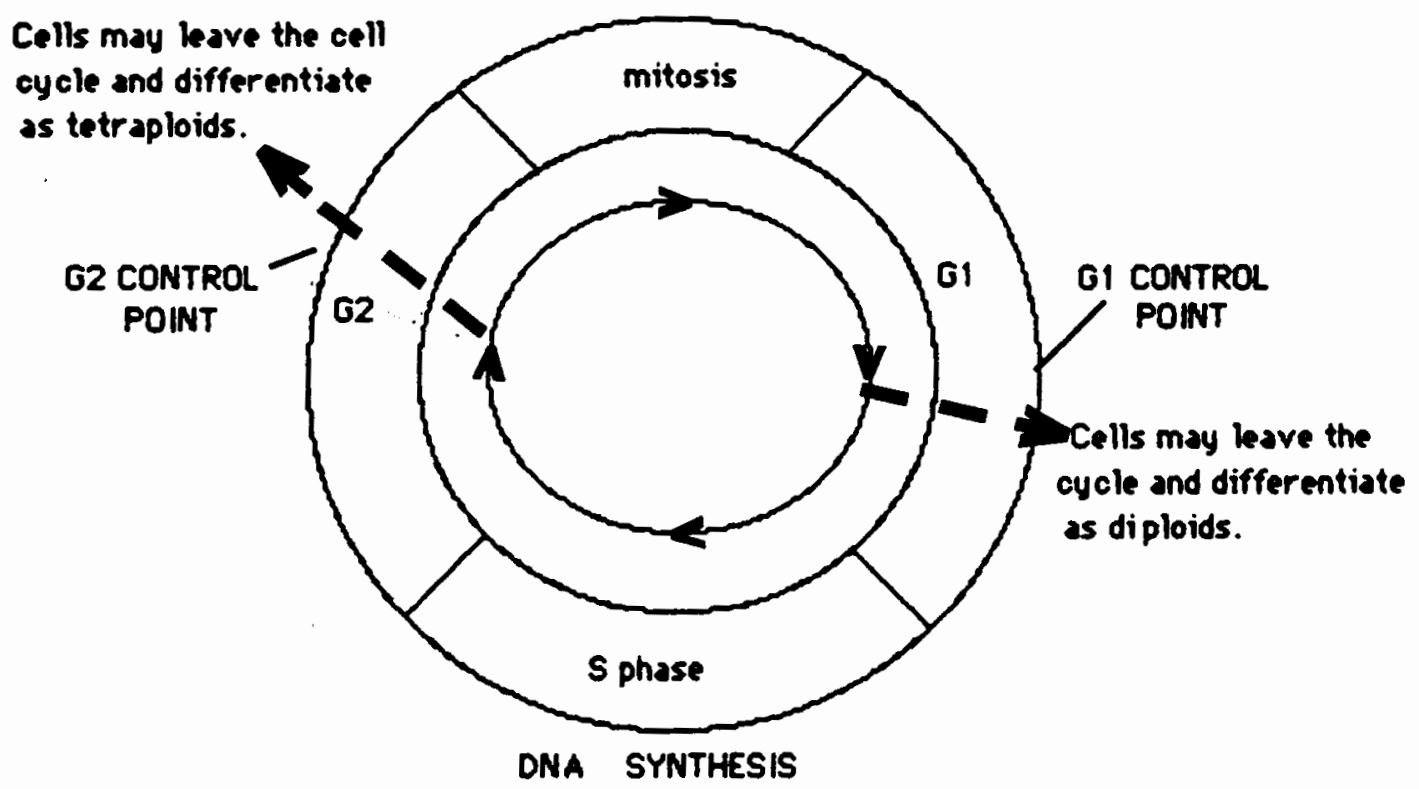

Figure 3. The concept of the cell cycle. The cell cycle consists of alternating periods of interphase and mitosis. Before mitosis can occur, the DNA of the chromosomes must be faithfully replicated. This DNA replication or synthesis, occurs in a defined part of interphase known as the $S$ phase, but it usually does not occupy the entire interphase period. The $S$ phase is preceded by an interval of time, called G1, in which cytoplasmic proteins are synthesized and organelles are replicated. The $S$ phase typically is followed by a post-DNA synthetic G2 period in which the cell prepares for mitosis. There is a control point early in G1 in which a decision is made either to enter the $S$ phase and replicated the DNA, or to leave the cell cycle and differentiate. In animal cells, all of the other stages of the cell cycle follow in order if the decision is made to enter $\mathrm{S}$ phase. However, plant cells appear to have a second control point in G2 at which a decision is made either to leave the cell cycle or to enter mitosis (Fosket, in Press). 
acid or IAA (Goodwin and Mercer, 1985). Figure 4 shows the structure of IAA and the synthetic auxin naphthalene acetic acid or NAA.

Indole-3-acetic acid is synthesized from the amino acid tryotoohan (Kutacek, 1985). The enzymes needed for this synthesis are most active in young meristematic tissues.
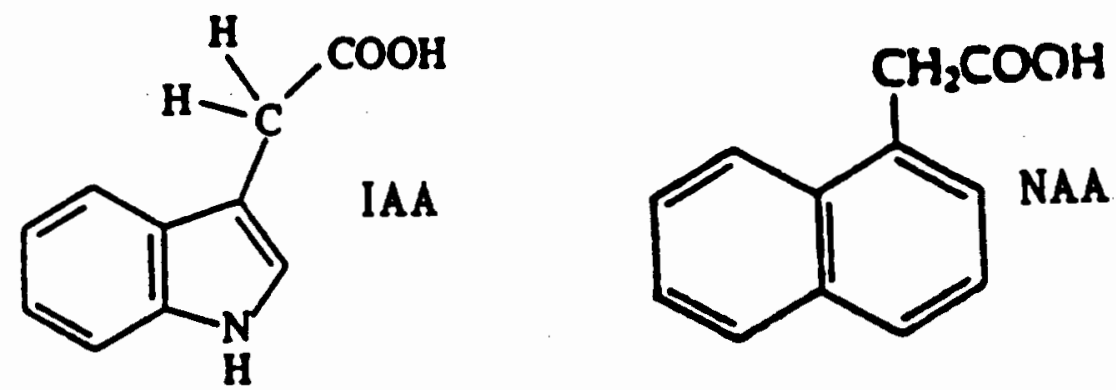

Eigure 4. The chemical structures of IAA and NAA.

The standard bioassays for detection of auxin-like activity are the Avena coleoptile curvature test and the coleptile straight growth test (Stout, in Press). These bioassays are sensitive to concentrations of IAA in the range of $0.02 \mathrm{mg} / 1$ to $0.2 \mathrm{mg} / \mathrm{l}$. Radioimmunoassay is an effective and commonly used method to measure physiological concentrations of IAA (around $10^{-9} \mathrm{~g}$ ) in plant tissues (Stout, in Press). Gaschromatography/mass-spectrometry is the method of choice to chemically define an auxin (Stout, in Press).

The primary effect of auxin is to promote stem growth by stimulating the cell elongation (Goodwin and Mercer, 1985). This primary effect is further complicated by the wide variation in response to differing concentrations and in that different tissues require different amounts of auxin for an optimal response (Goodwin and Mercer, 1985). Response is also dependent upon the physiological state of the affected tissue or cells and the concentrations of these growth factors. 
In young leaves--a major producers of auxins--and in roots the role of auxin is unclear. Low concentrations of auxins are known to stimulate growth (cell elongation) in roots. It was thought that auxins always stimulate growth (Goodwin and Mercer, 1985) but, current research indicates otherwise (Stout, in Press). When the concentration of auxin is high in roots there is an inhibition of root growth. This inhibition was originally thought to be due to the production of ethylene which is stimulated from the higher concentrations of auxin (ethylene is a potent root-growth inhibitor). When ethylene production is blocked inhibition is still observed (Stout, in Press).

The primary sites of auxin synthesis are in the apical meristems of shoots and in young leaves (Stout. in Press). Translocation of auxin can be a passive nonpolar transport via the phloem or an active unidirectional polar transport via certain plant cells that contain auxin transport proteins (Stout. in Press). Since normal physiological concentrations of aurin are quite low mechanisms probably exist to amplify its effect

Calcium as well as other cations are known to play a role in the transport of IAA (Stout, in Press). It is hypothesized that auxin may have an effect on cytosolic calcium levels which in turn may affect the calcium activated regulator protein, calmodulin (Stout, in Press). Calmodulin, could then regulate the activity of many enzymes, which in turn, regulate the activity of other enzymes. Thus the activation of calmodulin results in a cascade of physiological effects (Stout, in Press).

Auxins are thought to act by binding to specific receptor proteins on the cell membrane. This initiates a series of biochemical events leading to the observed physiological effects of the hormone (Stout, in Press). There are 
many known aurin binding sites, such as those on the endoplasmic reticulum, plasma membrane, and on the tonoplast; but, no specific receptor proteins have been identified (Stout, in Press).

The precise mechanism of operation for auxins is poorly understood. The promotion of growth and cell elongation is hypothesized to be initiated by the acidification of the primary cell wall (Rayle and Cleland. 1977). This theory states that auxins cause cells to actively pump out protons into the cell wall region which lowers the $\mathrm{pH}$ and activates enzymes that loosen the cell wall. The acid $\mathrm{pH}$ may also break calcium cross-links which further increases cell wall extensibility. This rapid response to IAA can occur within 10-25 minutes and the long-term responses of cell division, differentiation and morphogenesis can take place within hours or days. (Theologis, 1986). The passage of ten to twenty-five minutes is not enough time to account for cell elongation to transpire by protein synthesis alone (Theologis, 1986). However, because IAA also stimulates the synthesis of all types of RNA's, this latent response in growth can be explained.(Salisbury and Ross, 1983, Theologis, 1986). There is also some circumstantial evidence to indicate that auxins may regulate events leading to DNA replication during the cell cycle (Fosket, in Press). The currently accepted theory of its function is that auxin induced growth involves two phases: A rapid response resulting from direct and indirect auxin-induced proton secretion, and a later phase that is mediated by a separate primary action of auxins upon gene expression (Theologis. 1986). 
Cell Division Factors. Cytokinins will be discussed in following section.

a. Cytokinins. Cytokinins are a group of compounds, both naturally occurring in plants and of synthetic origin, that regulate cytokinesis (cell division). They are also responsible for many other physiological and developmental processes such as, delayed senescence, nutrient mobilization and chloroplast maturation (Fosket, in Press). They synergistically play a role with auxins in organ and tissue differentiation and these effects are often exploited in commercial tissue culture practices (Salisbury and Ross, 1985). This discussion of cytokinins will be limited to their role in cell division.

Zeatin is the cytokinin most commonly found in plants. It, and all other cytokinins are aminopurine derivitives (an adenine group with an attached side chain) (Fosket, in Press). There is one exception to this rule, diphenylurea derivities display weak cytokinin activity and are consequently considered cytokinins (Fosket. in Press). In addition to zeatin. other common cytokinins include, the synthetic kinetin. and the synthetic Benzylaminopurine, or BAP. Figure 5 shows the chemical structures of BAP and kinetin.<smiles>CCc1ccccc1O</smiles>

BAP<smiles>CCc1ccco1</smiles>

kinetin

Eigure 5. The chemical structures of BAP and kinetin.

Naturally occurring cytokinins exist in free and bound forms (Goodwin and Mercer, 1985). The free form is considered to be the active form (this 
is supported only by circumstantial evidence). The bound for $m$ is inactive. Cytokinins have been discovered bound to transfer RNA in all organisms and it is hypothesized that they may play a role in regulating protein synthesis (Fosket, in Press). Some bacteria and fungi secrete free cytokinins and, if they are intimately associated with a vascular plant, they can directly influence growth (Fosket, in Press).

These naturally occurring cytokinins are also constructed, in part. from a side chain that is derived from an isoprene unit (Fosket, in Press, Goodwin and Mercer, 1985). This side chain attaches to an adenosine monophosphate unit when acted on by the appropriate enzymes. Cytokinins are predominantly synthesized in the root. but they are also thought to be synthesized in embryos and young leaves (Fosket, in Press). Transport is passive, moving from the roots to the shoots through the rylem (Salisbury and Ross, 1985).

Cytokinin activity is assessed with cell proliferation bioassays. Radioimmunoassay is typically used to quantify the amount of cytokinin in a sample. and gas-chromatography/mass-spectrometry is the method of choice to chemically define these compounds (Fosket, in Press). The concentration of cytokinins in vascular plants are normally in the range of $0.01 \mu \mathrm{M}$ to $1.0 \mu \mathrm{M}$. The lower range of detectable limits is now at the level of $10^{-9} \mathrm{~g}$ (McGaw and Horgan.1985).

The mode of action of cytokinin is not known. It is suspected that cytokinins exhibit a promotive effect on RNA and enzyme formation. because inhibitors of RNA and protein synthesis effectively block cytokinin activity (Salisbury and Ross, 1985). This increase in protein synthesis is likely due to the stabilization of mRNA for various proteins, a mechanism 
which provides protection from premature degradation (Fosket. in Press. Salisbury and Ross, 1985). There is also some circumstantial evidence that cytokinin regulates events leading to mitosis during the cell cycle (Fosket, in Press). Finally, calcium, which does play a role in cytokinin-induced responses, may also play a role in regulating the calcium-calmodulin complex that activates the production of many other enzymes by creating a cascade effect (Fosket, in Press).

Growth Inhibition. Abscisic acid and ethylene will be discussed in the following section.

a. Abscisic Acid Abscisic acid, or ABA, was named for its contributing role in leaf abscission. It has been found in all angiosperms studied and in most gymnosperms (Goodwin and Mercer, 1985). It has many different physiological affects and all involve inhibition of growth.

Abscisic acid is synthesized in the entire plant and is consequently found in roots, stems, buds, leaves, fruits and seeds. It is formed from three isoprene units, derived from the melvalonic acid pathway (Goodwin and Mercer, 1985). The normal range of concentration is $20-100 \mathrm{ng} / \mathrm{g}$ fresh weight. Figure 6 depicts a representation of its structure.

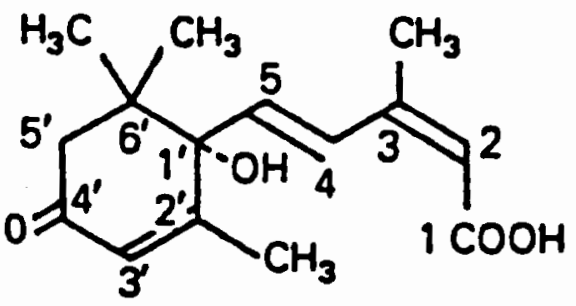

Eigure 6. The chemical structure of abscisic acid.

Many different bioassays are used in the study of the effects of $A B A$. 
Commonly used bioassays are: inhibiting the germination of isolated wheat embryos; inhibiting the growth of duckweed; inhibition of GA induced synthesis of alpha-amylase by barley alerone tissue; and the stimulation of stomatal closure (Goodwin and Mercer, 1985). The preferred method for identifying $\mathrm{ABA}$ is gas-chromatography/mass-spectrometry.

Abscisic acid also plays a role in gravity detection in roots, stomatal closure, bud dormancy and seed dormancy (Salisbury and Ross. 1985).

Little is known of the ABA's mode of action at the molecular level and none of its physiological effects can be fully explained. Since $A B A$ is a growth inhibitor, studies have been done to attempt to isolate where this regulation of growth occurs. What is known about this regulation is that $A B A$ does not block DNA transcription and that it exerts its main influence by blocking protein synthesis at a post-translational level, such as mRNA processing or translation (Goodwin and Mercer, 1985). Abscisic acid is known to alter membrane permeabilities that is exemplified by its affect on stomatal closure. Abscisic acid inhibits the efflux of $\mathrm{H}^{+}$and the influx of $\mathrm{K}^{+}$ into guard cells during stomatal closure caused by water stress (Goodwin and Mercer, 1985).

b. Ethylene. During the last century, when coal gas was used for public lighting, ethylene was discovered to exert hormonal effects. Trees near public lights had a tendency to shed leaves prematurely (Goodwin and Mercer, 1985). Soon after, plants were discovered to naturally produce ethylene when shipments of fruit would arrive in an over-ripened condition.

Ethylene is found in all plant tissues and is most easily detected by gas- 
solid chromatography and flame ionization (Goodwin and Mercer, 1985).

The physiological effects of ethylene are many, the most salient being the stimulation of abscission and the ripening of fruits (Salisbury and Ross, 1985). Ethylene stimulates the synthesis and secretion of cell wall dissolving enzymes which result in the softening of tissues (Goodwin and Mercer, 1985). Because of these effects ethylene is commonly used commercially to ripen fruits and too initiate flowering in several ornamental bromliad species (Salisbury and Ross. 1985).

Little is known about ethylene's mode of action but, it is believed to play many different roles in regulating plant growth. Reversable binding sites have been found on the endoplasmic reticulum and golgi membranes. One hypothesis is that it regulates some aspect of DNA transcription or RNA translation (Goodwin and Mercer, 1985).

\section{EUCARYOTIC ALGAL GROWTH}

Algae, like land plants, vary greatly in their size. Seaweeds can grow to over 200 feet in length. The kelp, Macrocystis (Phaeophyta) is the largest known alga (Prescott, 1968), and there are microscopic unicellular cocoid algae, such as Pelagococcus subviridis (Chrysophyta), that are less than 3 $\mu \mathrm{m}$ in diameter (Shapiro et al., 1989). Given the precursors of light, water, $\mathrm{CO}_{2}$, and various minerals, algae can grow and reproduce within the limits of their genetic and environmental constraints.

Growth is measured differently between macroscopic and microscopic algae. Growth in macroscopic algae is typically defined as a permanent increase in size. Measurement of this growth is usually determined by the 
increase in dry weight or fresh weight. Growth in unicellular algae is measured and defined by the increase in total cell number and biomass (Soeder and Stengel. 1974). This increase can be determined by manual counting or with a flow cytometer. When assessing growth both components need to be considered. Many algae will continue to divide but become progressively smaller with each division and no "real" increase in biomass occurs (Soeder and Stengel, 1974).

The study described in this thesis defined growth as an increase in total cell number.

\section{CONTROL OF ALGAL GROWTH}

Growth is predominantly controlled by an alga's genetic make-up, external environmental factors, and chemicals that may have a promotive or inhibitory effect. Interactions occur among these three components that allow an alga to monitor and respond to changes in its environment.

\section{Genetic Control}

Genetic information is encoded in the nuclear and organelle DNA of all algae (cyanobacteria are not considered here as algae). The given genetic makeup will determine the general growth pattern of an alga, how it reproduces, and the type of growth it exhibits. Environmental and chemical stimuli of ten feedback to the genetic level of control by directly inhibiting or stimulating protein synthesis. This allows an alga to change from one type of metabolism to another.

There are certain advantages to genetic level control. One of these is characterized by a mechanism which responds to changes in the 
environment, producing rapid and specific synthesis of proteins. These proteins can have specific function or accelerate a metabolic pathway. Very complex responses to changes in metabolism can occur through the use of genetic control. This can lead to increased fitness in a predictive environment. Lee (1980) gives one such example in Botrydium (Chrysophyta), an alga that encysts to survive dry periods. Darley (1982) mentions that in diatoms nitrogen limitation is an identified trigger to induce resting spore formation. Mechanisms such as these increase chances of survival until conditions improve.

Certain costs are associated with this type of control. Cells need the internal machinery to respond to changes (polymerases, synthetases, etc.). This ability to respond is most efficient when the alga is growing well and the environment is predictable. When unpredictable conditions arise the alga may be programed to respond to the initial environmental cue by committing available reserves towards some protective process, such as encysting. If conditions change again there may be no resources available to allow response to that change thereby decreasing fitness and that is the cost of responding to miscues (Rueter, personal communication).

\section{Environmental Control}

Algae are adapted to live and grow in many varied and extreme conditions. They may grow beneath polar ice, on permanent snow fields, on rock surfaces, even among the hair scales of the three-toed sloth (Darley, 1982. Lee, 1980, Prescott. 1978. Round, 1965). Most algae live out their entire life cycle in an aquatic environment. This type of environment is typically more stable than a vascular plant's in terms of temperature and 
moisture. In the event that a wet habitat, such as a pond, is drying out most of the indigenous algal species can survive by encysting or forming spores until conditions are again favorable for growth.

If nutrients are not severely limiting, light and temperature are the major regulators of growth. The dominant algal species will vary with the changing conditions, because day length and temperature variations throughout the year help to maintain the diversity of species in a given aquatic environment.

Availability and intensity of light will directly influence the growth of an alga. Under intense light cell growth is limited by the rate at which carbon is fired. These cells typically have less chlorophyll per cell and smaller chloroplasts. In these cells, more resources are directed toward fixing carbon into carbohydrates than to fixing carbon into proteins used in the photosynthetic machinery (Darley, 1982, Soeder and Stengel, 1974)).

Light limited cells grow more slowly. They have maximized the use of available light energy by increasing their photosynthetic machinery. These cells typically have larger chloroplasts and more chlorophyll per chloroplast. Carbon fixation declines at low light intensity as more resources are directed toward chlorophyll synthesis and maintenance of the photosynthetic machinery. When light levels decrease further carbon firation stops, growth is further slowed, and there is only a small increase in the photosynthetic machinery because the cell has physically run out of space (Darley, 1982). 


\section{Chemical Control}

The following discussion, concerning chemical control of growth, will be confined to what is known about plant growth regulators and their effect on algal growth. Unfortunately very little work has been in this exciting area of algal physiology.

Many algae, especially the multicellular seaweeds, demonstrate apical dominance, photoperiodism, organized differentiation of complex specialized structures, and other effects which suggest that they may be under the control of endogenous growth regulators (Provasoli and Carlucci. 1974). In fact, plant growth regulators have been found in some algae and more are likely to be discovered as assays are improved (Goodwin and Mercer, 1985).

Historically algal/plant growth regulators have been investigated through extraction, bioassay, and the observance of any physiological response when added to a growing culture of algae (Provasoli and Carlucci, 1974). Extraction and bioassay allowed investigators to make definite claims that a hormone-like substance was produced by an algae. A physiologic response to the addition of plant growth regulators was considered by some investigators to indicate the existence specific receptor sites. Other investigators further expanded this possibility to claim that this would also indicate production of that specific growth regulator by the alga in question (Provasoli and Carlucci, 1974).

Growth Promoters. The following section will discuss the promotive effect of gibberellins, auxins, and various organic acids. 
a. Gibberellins. Gibberellic acid-like activity has been found at low levels in most unicellular and muticellular algae that have been investigated (Provasoli and Carlucci, 1974, Radley, 1961). In unicellular algae, $\mathrm{GA}$ is generally associated with a slight increase in growth rate whereas, in multicellular algae there is usually a non-specific increase in growth (Provasoli and Carlucci, 1974). Recent work by Bralczk et. al. (1978) confirms this non-specific increase in growth in the algae Euglena gracilis. Bralczk et. al., (1978) found an increased rate of RNA synthesis to be responsible for this growth increase.

Some algae demonstrate no response to GA (Provasoli and Carlucci, 1974). The desmid Micrasterias shows no response to GA except for GA having a lethal effect at a $\mathrm{pH}$ of 5 when concentrations are above $5 \mathrm{mg} / 1$ $10 \mathrm{mg} / \mathrm{l}$ (Wood and Berliner, 1979). Controls at $\mathrm{pH} 5$ with no added GA showed no detrimental effects from the acidity of the media (Wood and Berliner, 1979). As growth in most algal species is affected by exogenously added GA it is possible that control of growth and morphogenesis may be at least partially regulated by this growth promoter, even if it is not yet possible to state that algae produce GA (Taylor, 1977).

b. Auxins. Auxin-like activity has been found in compounds isolated from all of the different phyla of algae. Auxins have only been chemically identified in the green algae Caulerpa paspalojdes Chlorella pyrenojdosa, and in the brown alga, Undaria pinnatifida (Grotbeck and Vance, 1972. Prikryl et al., 1985, Zhang et al., 1989).

The general effect of auxins in unicellular algae is to stimulate growth. but responses vary from inhibition to stimulation (Berliner, 1981, 
Provasoli and Carlucci, 1974. Wood and Berliner, 1979). In multicellular algae auxin appears to be involved in the control of apical dominance, but again response varies from no effect to an observable response (Buggeln, 1976. Provasoli and Carlucci, 1974).

In Characean algae it is known that a sudden rise in $\mathrm{Ca}^{+2}$ levels stops cytoplasmic streaming (Pharis and Reid, 1985). A sudden increase in IAA or a similar compound might act by affecting calcium levels by causing leakage out of vacuoles which in turn activates plasmalemma pumps that are sensitive to calcium and this either stimulates or inhibits growth (Pharis and Reid, 1985). The mechanism as to how this would work in vascular plants is still being worked out and it is likely that calmodulin (a calcium activated regulator protein) will be found to play some role (Pharis and Reid, 1985).

Scott (1984) warned that some caution must be taken when interpreting growth responses in early algal studies. At that time ethanol was widely used as a solvent in preparations of cultures. Ethanol is believed to increase growth in algal cultures by contributing an available carbon source (Scott. 1984). It is an essential carbon source for some of the phagotrophic algae and other species of algae can assimilate ethanol as part of their carbon supply (Droop. 1974). However, no studies have been found that demonstrate a dramatic increase in growth, it is therefore, concluded that ethanol effect must be minimal.

c. Organic Acids. Certain organic acids are known to enhance cell growth by being an alternative or supplemental source of carbon (Droop. 1974). Some strains of Euglena gracilis require organic acids, such as 
acetic and butyric acid, as a necessary carbon source for optimal growth (Droop, 1974).

Most plant growth factors are substances that have small molecular weights and possess an attached organic acid segment. It is possible. but not likely, that binding proteins recognize the acid segment of some plant growth regulators, consequently an organic acid could cause a response similar to that caused by a plant growth factor.

Cell Division Factors. Cytokinnins will be discussed in the following section.

a. Cytokinnins. Cytokinnin-like activity has been found in many algae. They usually affect unicellular algae by increasing the rate of cell division. however, total yield increases only slightly (Provasoli and Carlucci, 1974). Cytokinnins have been isolated from brown and red algae and in the green alga, Chara globularis (Salisbury and Ross, 1985, Zhang et al., 1989). C. globularis belongs to the order Charales in the Class Charophyaceae, a group Zhang et al. (1989) considers to be the ancestors of land plants. This group maintains a persistent mitotic spindle, and it is thought that the phragmoplast, which is characteristic of cytokinesis in vascular plants, evolved from this structure (Brook, 1981, Pickett-Heaps, 1975).

Cytokinnins appear to play a role in cytokinesis by increasing the transition of cells from G2 (a period in which the cell prepares for mitosis) to mitosis by increasing the rate of protein synthesis (Goodwin and Mercer, 1985. Salisbury and Ross, 1985). Addition of kinetin, a synthetic cytokinnin, to the green alga Chlorella pyrenoidosa resulted in an increase in cell division as a consequence of the shortened lag phase in the cell cycle 
(Vance, 1987). Berliner (1981) also found that kinetin affected the lag phase of the cell cycle for the desmid Cosmarium.

Growth Inhibitors: Abscisic Acid and Lunularic Acid Abscisic acid and lunularic acid are considered to be inhibitors of growth. ABA has only been identified in the green alga Stigeoclonium. But other algal species are known to produce ABA-like substances (Hussain and Boney, 1973. Jennings. 1969; Zhang et al., 1989). Lunularic acid, LA is postulated to be another growth inhibitor present in algae. Lunularic acid was first isolated from liverworts in the early 1970's and was found to have biological activity similar to ABA (Pryce 1971, Pryce 1971, Pryce, 1972, Salisbury and Ross, 1985). LA responds to light by regulating thallus length and by inhibiting the germination of gemmae on the parent plant in liverworts (Salisbury and Ross, 1985). Under continuous light conditions LA levels increase in liverworts which results in a dormancy response (Valio et. al., 1969). Figure 7 shows the chemical structure of lunularic acid.

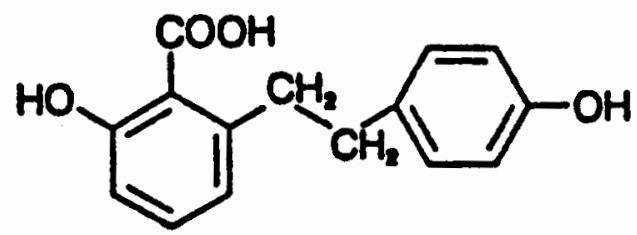

Eigure 7 The chemical structure of lunularic acid.

There is conflict over whether LA or its derivatives occurs in all phyla of algae. Price, (1971) who did the initial work and isolation of LA from algae, maintains that it is common in most algae. Whereas, Gorham (1977) tried to reproduce Price's 1972 findings, and with the use of more sensitive techniques, and was unable to isolate LA in any of the algae that he studied. Price's finding of LA is commonly quoted as evidence of its 
existence in most algae, when in fact, the conflicting data shows no clear evidence for the occurrence of LA in algae.

\section{PLACODERM DESMIDS}

\section{General Description}

An estimated 11,000 species and varieties of algae fall into the category of placoderm desmids. These algae are considered by many to be the most microscopically beautiful cell known (Prescott, 1968). They are mostly unicellular and are formed from two equal halves or semicells that are mirror images of each other. They are divided by an isthmus or if an isthmus is absent, the cell contents are divided by a nucleus (Prescott. 1968). The cell walls are elaborate and no two planes look the same. These algae have specialized pores through which mucous is secreted to aid in movement (Prescott, 1968). Desmids are relatively slow growing organisms. They have available mechanisms to maximize photosynthesis by altering their position in the water, which optimally exposes their elaborately folded chloroplasts. Due to their elaborate wall structures and division pattern, they are considered good candidates for the study of physiologic factors that involve cell division (Berliner,1981).

\section{The Life Cycle and Morohology of Closterium moniliferum}

The cells of Closterium moniliferum are lunate, and slightly tumid at mid region (Figure 8). They are composed of two semicells which are separated by a central nucleus. Each semicell contains a chloroplast which cleaves prior to cell division. The nucleus divides and each daughter 


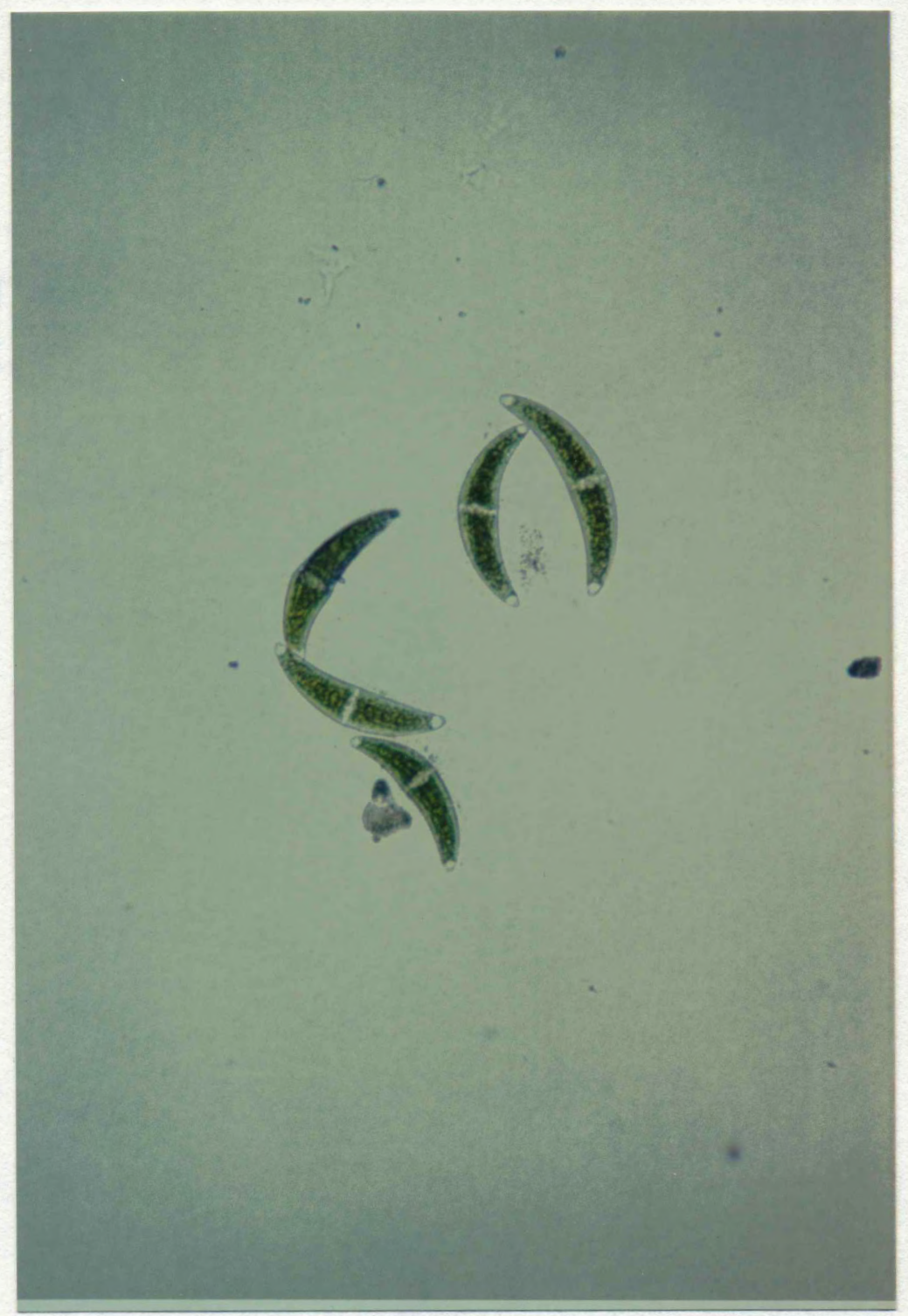

Figure 8. Photomicrograph of mature cells strain 49E Closterium moniliferum. 
nucleus moves to the cleavage position of the chloroplast. After division, the daughter cell is comprised of one semicell from the parent and one semicell produced from cell wall secretions (Figure 9). When mature, the semicells are mirror images of each other.

Sexual reproduction occurs when the im mature daughter cells pair soon after cell division. Conjugation papillae for $m$ and the cell contents from both daughter cells are deposited within a hyaline bladder (Figure 10). The nuclear material fuses to from a zygote, which is the only diploid stage in the life cycle.

The first meiotic division occurs around the onset of germination. Cleavage takes place before the second meiotic division and one nucleus in the newly formed protoplast degrades. The protoplasts then become lunate and continue to grow until hatching (Brook, 1981). After hatching these new cells will grow to their mature size and repeat the cycle of reproduction either asexually or sexually.

Zygotes typically require a maturation time of 1-2 months in the dark before germination occurs (Lippert. 1967). In the experiment conducted for this work. zygotes were occasionally observed to germinate within the 7 day treatment period without this "maturation" or loss of chlorophyll that is typically observed in zygote production and germination.

\section{ST ATEMENT OF RESEARCH GOALS}

Vascular plants are considered to have evolved from the ancestors of green algae. Consequently, it would be reasonable to assume that similar, or, indeed, the same growth factors in vascular plants had initially or concurrently evolved in the algae. Current research holds this generally to 


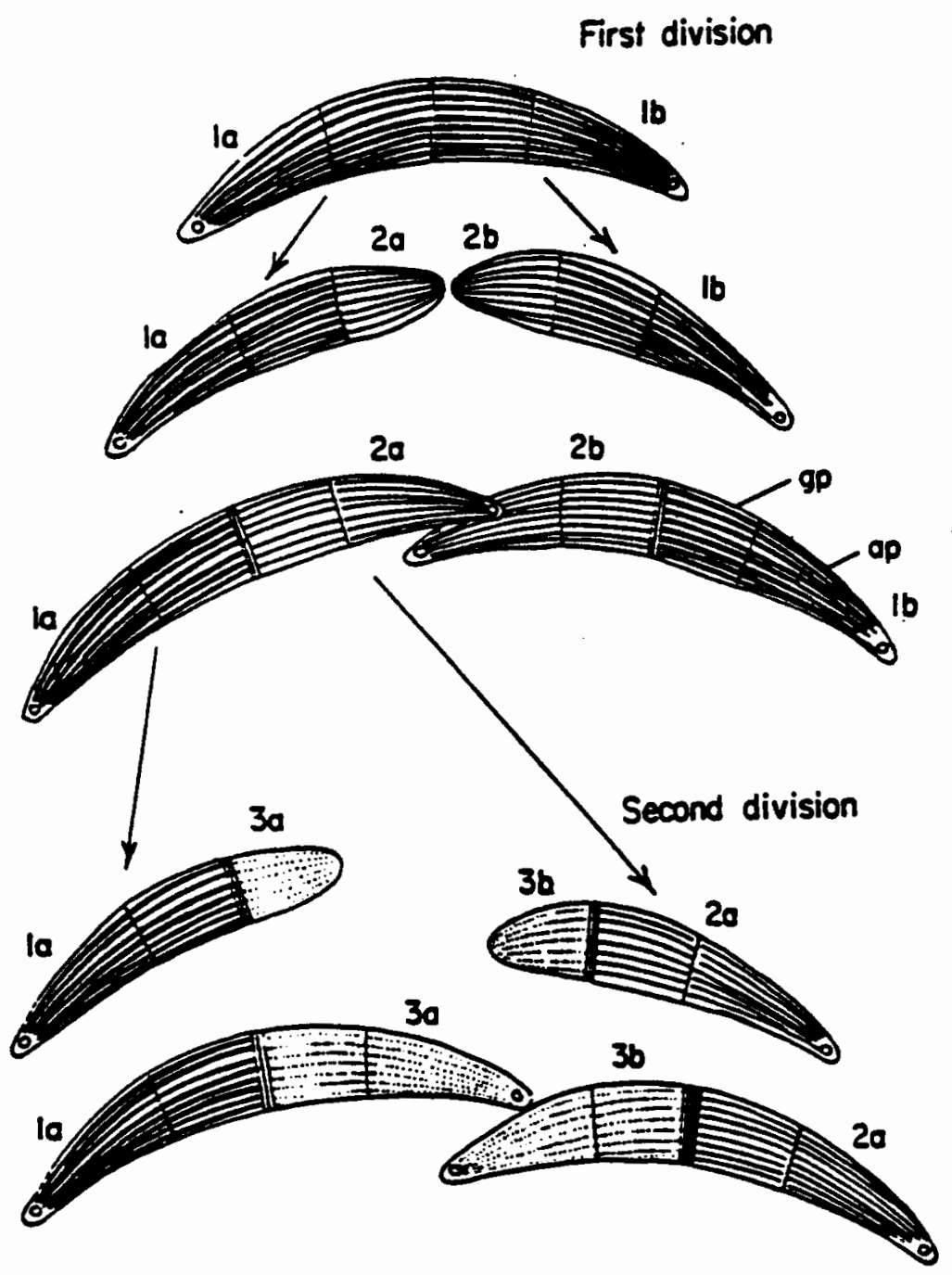

Bipure 2 Cell division-- Clasterivm type. Diagram showing two successive divisions of a Closterium cell to illustrate the distribution of the parent cell walls to the daughter cells. The walls of the $18 t$ generation cell ( 1 a and $1 b$ ) are drawn with heavy longitudinal striations; those of the 2 nd generation ( $2 a$ and $2 b$ ) with lighter shown as dotted lines. $8 p$ - girdle portion; ap = apical portion (Brook, 1981). 
Sexual Reproduction (Conjugation)
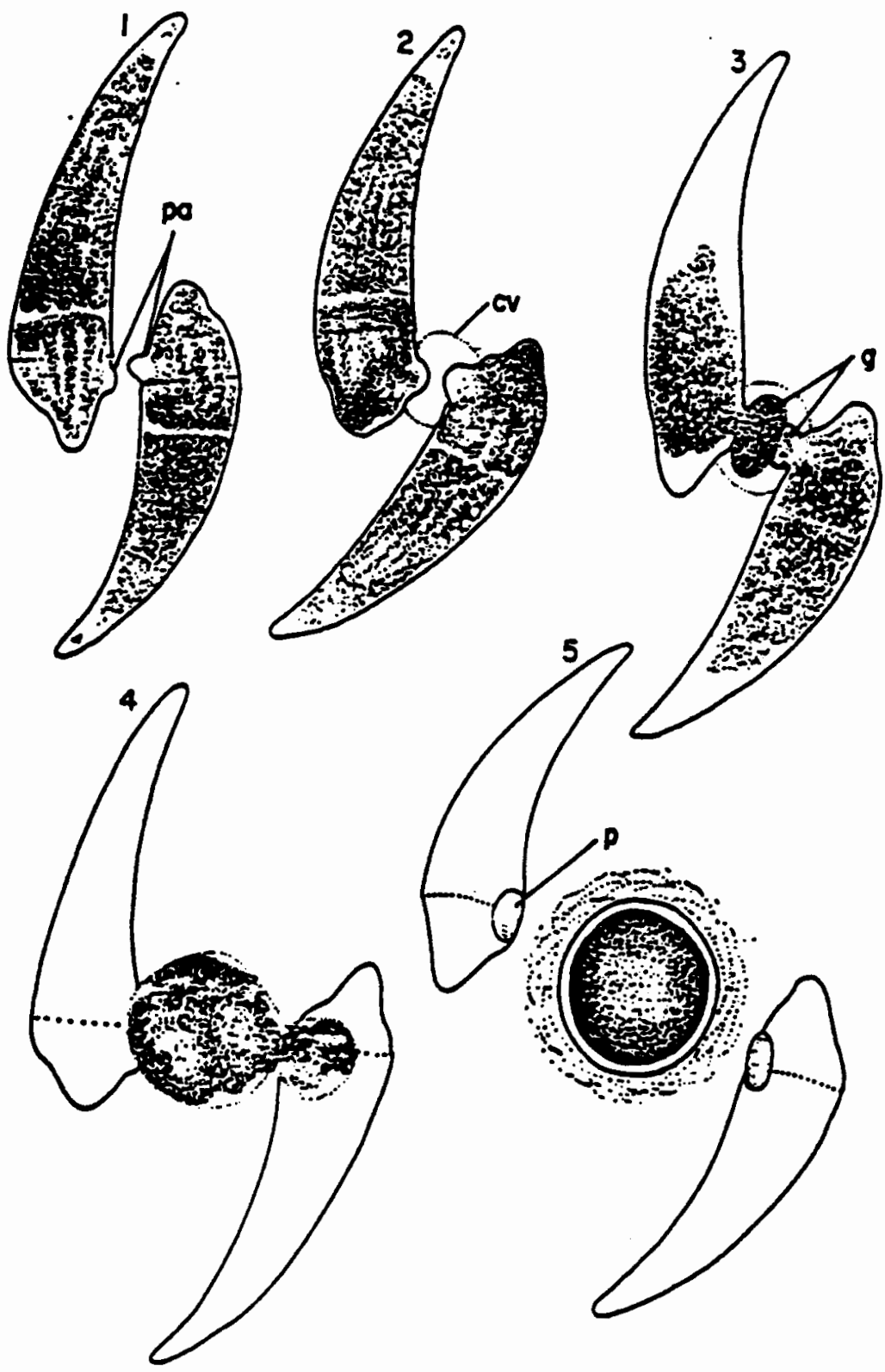

Eigure 10 Conjugation in Closterium: the $C$ moniliferum-ehrenbergif type. 1 The pairing of immature daughter cells and formation of conjugation papillae; 2 secretion of hyaline conjugation vesicle; 3 initiation of movement of gametes; 4 final stages of gamete fusion; 5 mature zygospore and empty cells showing conjugation pore. $\mathrm{Cv}$ conjugation vesicle; 8 - gametes; $p$ - conjugation pore; $p$ - papillae (Brook, 1981). 
be true, since IAA, kinetin. $A B A$ and GA have been found in some algae, and compounds with IAA-like, kinetin-like, ABA-like, and GA-like activity. have been found in most algae investigated to date (Provasoli and Carlucci. 1974, Raub et al. , 1987, Zhang et al., 1989).

Very little work has been done on algae and plant growth regulators. Few studies have been done recording the effects of all classes of plant growth promoters. A search of the literature has revealed no studies investigating both plant growth promoters and inhibitors on algal growth. No work was reported on the effects of BAP (a synthetic cytokinin) or ABA on algal growth. The question being asked in this study is will GA. NAA. BAP. ABA, and various organic acids will affect the growth of Closterium moniliferum .

A physiological response in Closterium moniliferum is anticipated when BAP. NAA, GA and ABA are applied exogenously to the growth media. A response would be indicated by an increase or decrease in growth rate, rate of zygote formation, or change in morphology when compared to the controls. A response is expected because earilier studies in other algae with similar classes of compounds have demonstrated physiological responses (Provasoli and Carlucci, 1974). A physiological response to a specific plant growth regulator could indicate recognition of that compound by proteins in the alga. A physiological response suggests that Closterium moniliferum utilizes and possibly produces specific plant growth regulators. However. only extraction. chemical analysis. and bioassay could confirm this production.

Very little is known about how the various classes of plant hormones work as their sites of action and production are generally non-specific 
(Salisbury and Ross, 1985). The use of a clonal population of a homothallic strain of Closterium moniliferum (a unicellular green alga that forms zygotes with no apparent environmental stresses), provides a model system that could be used in future studies examining specific sites of hormone action at a cellular level. 
CHAPTER II

\section{MATERIALS AND METHODS}

\section{THE ORGANISM}

The organism used was obtained from a clonal culture of a homothallic strain of Clasterium moniliferum that produces a single zygospore during sexual reproduction. This strain is presently stored in the Culture Collection of Algae at Portland State University, Portland, Oregon.

Strain $49 \mathrm{E}$ was originally isolated by C. L. Christensen from a pond sample, collected by Janet Cruden, near her home at $14344 \mathrm{~N}$. W. Springville Rd., Portland, Oregon, in April, 1988. The average size of a mature cell of strain $49 \mathrm{E}$ is $190 \mu \mathrm{m} \times 31 \mu \mathrm{m}$ : zygote measurement is $60 \times 60$ $\mu \mathrm{m}$. This strain reproduces sexually and asexually when cultured in Soil Water Media under standard light conditions (Lippert, 1967). Limited sexual reproduction was noted when strain $49 \mathrm{E}$ was cultured in Ichimura's Growth Media (IGM) and asexual reproduction was not as vigorous when compared to Soil Water Media (Hamada, 1978). The recipe for IGM was taken from Hamada's (1978) publication on environmental factors that influence zygote formation and germination (Table I). 


\section{TABLE 1}

RECIPE FOR ICHIMURA'S

GROWTH MEDIA

\begin{tabular}{rc}
\multicolumn{1}{c}{ INGREDIENT } & AMOUNT \\
CA(NO3)-4H2O & $0.15 \mathrm{~g}$ \\
KNO3 & $0.10 \mathrm{~g}$ \\
Na2glycerophosphate-5H20 & $0.005 \mathrm{~g}$ \\
MgSO4-7H20 & $0.04 \mathrm{~g}$ \\
Vitamin stock \#\# & $0.01 \mathrm{ml}$ \\
P IV metals ** & $3.0 \mathrm{ml}$ \\
Tris & $0.5 \mathrm{~g}$ \\
Distilled H2O & $997 \mathrm{mls}$
\end{tabular}

\#\# Vitamin Stock:Recipe

Vitamin B12 $100 \mathrm{mg}$

Biotin $1 \mathrm{mg}$

Thiamine $\mathrm{HCl} 1 \mathrm{mg}$

Distilled H2O $\quad 1000 \mathrm{mls}$

final concentration in media Vitamin B12

Biotin

Thiamine $\mathrm{HCl} \quad 10.0$ ug

0.1 ug

0.1 ug
** P IV Metals

NA2EDTA

$\mathrm{FeCl3}-6 \mathrm{H} 2 \mathrm{O}$

$0.750 \mathrm{~g}$

$\mathrm{MnCl}-4 \mathrm{H} 20 \quad 0.041 \mathrm{~g}$

$\mathrm{ZnCl}$

$0.005 \mathrm{~g}$

$\mathrm{CoCl} 2-6 \mathrm{H} 2 \mathrm{O} \quad 0.002 \mathrm{~g}$

$\mathrm{NaMo4} \quad 0.004 \mathrm{~g}$

Distilled H2O $500 \mathrm{~m} / \mathrm{s}$

$0.097 \mathrm{~g}$

$0.004 \mathrm{~g}$
$500 \mathrm{~m} / \mathrm{s}$ 


\section{PREPARATION OF MEDIUM}

The organism was grown in IGM because it is a defined media especially developed for Closterium (Hamada, 1970). The water used in the medium, (and in all solutions) was glass distilled water. Media was mixed in 1 liter batches and the $\mathrm{pH}$ was adjusted to 7.5 at 21 degrees centigrade with either $1 \mathrm{~N} \mathrm{HCL}$ or $1 \mathrm{~N} \mathrm{NaOH}$.

The agar used was purified plant cell culture tested from Sigma, product number A 7921. The phytohormones used were aiso from Sigma and they included: 1-Naphthaleneacetic acid (NAA), a synthetic auxin; 6Benzylaminopurine (BAP), a synthetic cytokinin; Gibberellic acid (GA3), a naturally occurring phytohormone; and Abscisic Acid (ABA), a growth inhibitor in vascular plants. All phytohormones were dissolved in $1 \mathrm{ml}$ of warm $0.5 \mathrm{~N} \mathrm{NaOH}$ and then a stock solution was made by the addition of media, bringing the final volume to $30 \mathrm{ml}$. The appropriate aliquots were than added to IGM to attain the desired hormone concentrations and to bring the final volume up to $50 \mathrm{ml}$. Purified agar in the amount of 0.4 grams was added to the media and dissolved by heating on a hot plate or in a microwave.

Preliminary work tried dissolving GA3 in a small volume of ethanol, as in vascular plant work this method was considered equivalent to dissolving GA3 in warm NaOH (Arditti and Dunn, 1969, Sigma 1989). No growth effect was noted in the organism. Ethanol was not a suitable solvent for all of the compounds in this investigation, and additional controls would had to have been performed to control possible ethanol effects (Grotbeck and Vance, 1972). NaOH was already being used to adjust the $\mathrm{pH}$ of the media 
and was consequently deemed to be a more appropriate solvent.

The organism was transferred from a liquid IGM to a semisolid media made from $0.8 \%$ agar mixed with IGM on $35 \mathrm{~mm} \times 10 \mathrm{~mm}$ glass dishes in order to facilitate observations of individual cells during the treatment period. Preliminary experiments were performed to determine what percent agar would maintain good growth over a 0-14 day period. Under the given laboratory conditions the cultures were not continuously axenic.

Six to twenty-five cells were inoculated on each plate by use of a capillary pipette and standard transfer techniques (Stein, 1973). The plates were then covered and set on a shelf in the culture room. Sir to twelve replicate runs were conducted for each concentration of plant growth regulator and for the controls. Three to four replicate runs were made for each concentration of organic acids tested and for the respective controls.

Provasoli and Carlucci's (1974) summary of early hormone work reported "active" levels in the range of $0.01 \mathrm{mg} / 1$ to $20.0 \mathrm{mg} / 1$ of exogenous hormone in the growth media. The concentrations used for this study were based upon these levels which are in the normal physiologic range. Concentrations used in these experiments are reported in both $\mathrm{mg} / \mathrm{l}$ and in $\mu \mathrm{M}$ to facilitate comparisons between similar compounds that have comparable bioactivity but different molecular weights and with papers that reported concentrations in $\mathrm{mg} / \mathrm{l}$.

BAP was tested at concentrations of $0.02 \mathrm{mg} / 1(0.09 \mu \mathrm{M}), 0.2 \mathrm{mg} / 1(0.9$ $\mu \mathrm{M}), 2.0 \mathrm{mg} / 1(9 \mu \mathrm{M}), 5.0 \mathrm{mg} / 1(22 \mu \mathrm{M})$, and $10.0 \mathrm{mg} / 1(44 \mu \mathrm{M})$. GA was tested at concentrations of $0.04 \mathrm{mg} / 1(0.11 \mu \mathrm{M}), 0.4 \mathrm{mg} / 1(1.1 \mu \mathrm{M}), 4 \mathrm{mg} / 1$ $(11 \mu \mathrm{M}), 10 \mathrm{mg} / 1(29 \mu \mathrm{M})$, and $20 \mathrm{mg} / 1$. $(58 \mu \mathrm{M})$. NAA was tested at the following concentrations of $0.04 \mathrm{mg} / 1(54 \mu \mathrm{M})$, and $20 \mathrm{mg} / 1(108 \mu \mathrm{M})$. ABA 
was tested at the following concentrations of $0.04 \mathrm{mg} / 1(0.15 \mu \mathrm{M}), 0.4 \mathrm{mg} / 1$ $(1.5 \mu \mathrm{M}), 4 \mathrm{mg} / 1(15 \mu \mathrm{M}), 10 \mathrm{mg} / 1(38 \mu \mathrm{M})$, and $20 \mathrm{mg} / 1(76 \mu \mathrm{M})$.

Organic acids with small molecular weight were tested to assess any acid effects on growth. These acids were: acetic acid (MW 60.05), butyric acid (MW 88.1), and benzoic acid (MW 122.12). The concentrations tested, ranged from $0.1 \mu \mathrm{M}$ to $380 \mu \mathrm{M}$. The acids were added to a stock solution of media, then appropriate aliquots were diluted to yield the desired concentration.

\section{ENVIRONMENTAL CONDITIONS}

Stock cultures of the organism under investigation were originally kept in both IGM and in Soil Water Media (Table I). Cultures were originally transferred from Soil Water Media into IGM and then transferred at intervals to maintain active growth. When new inoculations of IGM from Soil Water Media were necessary, the algae were acclimated for two weeks before use in the new media. Cultures were grown at $21+/-1$ degree centigrade in the culture room at Portland State University, under coolwhite fluorescent tubes set on a cycle of 16 hours light and 8 hours dark. All experiments were run under these standard conditions with the exception of the continuous light experiment. The only difference here, was that the cycle was maintained at 24 hours of light. Refer to Figure 11 which depicts the layout of the culture room.

Experiments were conducted on a $0.8 \%$ purified agar made up with Ichimura's Growth Media to which the various phytohormones were added. Since Closterium moniliferum is able to glide and move freely on top of, 
ssajgojd

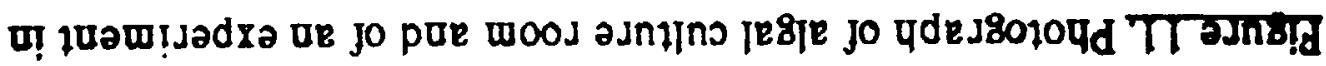
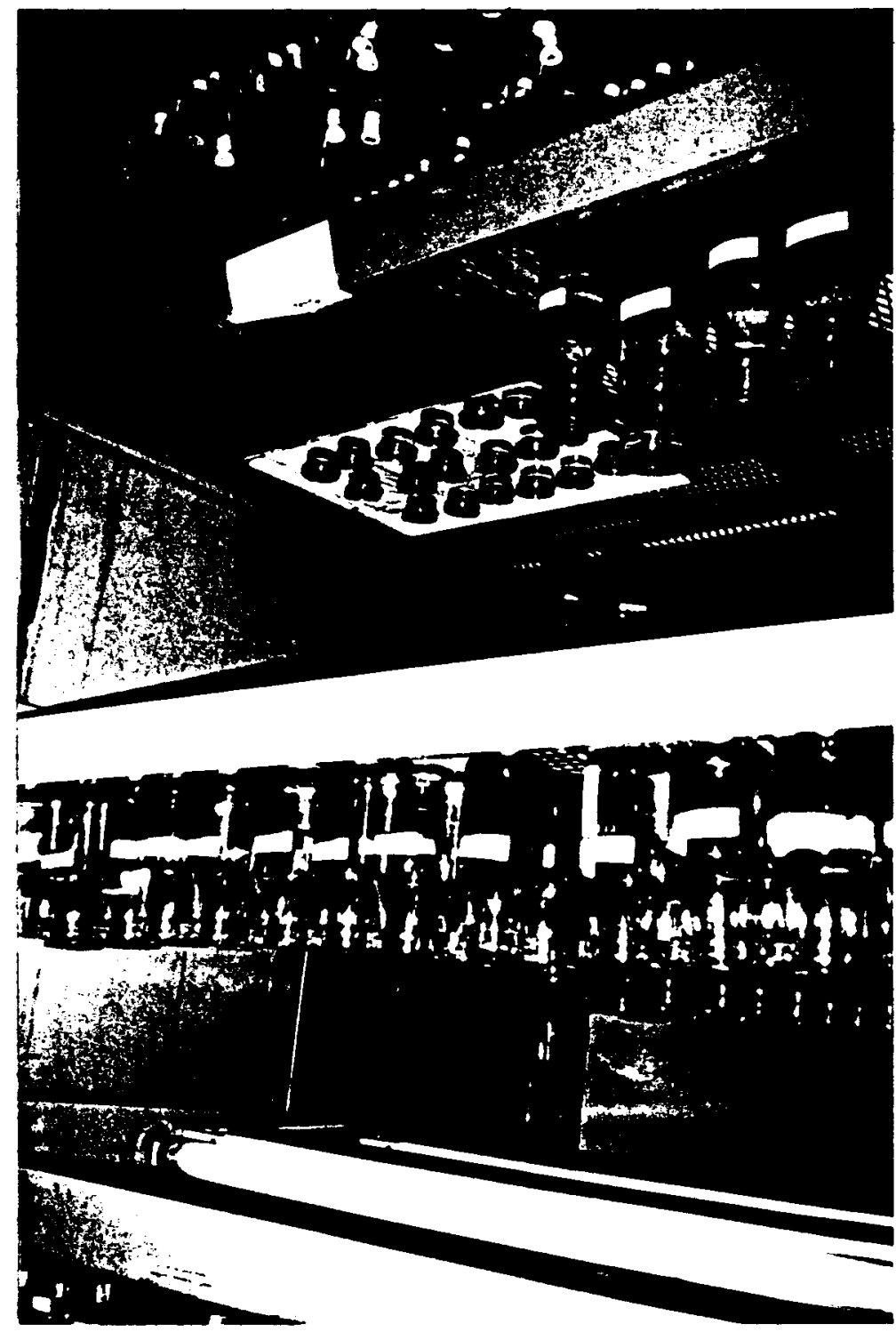
and through the agar, nutrient depletion was not of concern. The alga could move to new locations if the surrounding nutrients became depleted. Locomotion was achieved by gliding on secretions emitted from mucilage pores, or end over end flipping (Brook, 1981). These pores also allow easy penetration of substances into the cell. The pores fully penetrate the secondary cell wall which allows partial exposure of the microfibrils in the primary cell wall which lacks pectin in these areas (Brook, 1981). Owing to these unique features, there should be adequate absorption of nutrients and any added plant growth factors.

\section{PREPARATION OF GLASSWARE}

Glass culture dishes $(35 \mathrm{~mm} \times 10 \mathrm{~mm})$ used in all experiments were washed and rinsed 10 times in tap water and air dried. All other glassware used were washed in tap water with a final rinse of distilled water, then air dried. Erlenmeyer flasks were used in the final media preparation. They were rinsed once with IGM before use.

\section{pH MEASUREMENT}

The media was adjusted to $\mathrm{pH} 7.5$ at 21 degrees centigrade before the addition of phytohormones, organic acids and agar on available $\mathrm{pH}$ meters. Because the growth medium used in the experiments was semisolid. narrow range $\mathrm{pH}$ paper ( $\mathrm{pH} 6.0$ - 8.0) from Micro Essential Laboratories. Brooklyn. New York, was used at the beginning and at the end of each run to determine the approximate $\mathrm{pH}$ and if a change in $\mathrm{pH}$ occurred. No change in $\mathrm{pH}$ was noted for any experimental run. The $\mathrm{pH}$ ranges were well within 
the physiological tolerances of the organism under investigation. The typical $\mathrm{pH}$ of the control plates remained stable at $\mathrm{pH} 7.6$.

\section{PHOTOGRAPHY}

A $35 \mathrm{~mm}$ Zeiss Ikon camera was used with a Zeiss microscope for the photography and observation of morphology in Closterium moniliferum . Photographs were taken directly from the experimental plates with Kodachrome Color Reversal Film 40 (Type A) DX KPA 135-36. Shutter speed, unless otherwise indicated, was $1 / 10$ th of a second. Magnification of the cells was $40 \mathrm{X}$ or $100 \mathrm{X}$.

\section{MONITORING OF CELL GROWTH}

Cells were counted at day zero and repeat counts were made of living cells and any zygospores at day seven. Cell morphology was noted at these readings.

\section{STATISTICAL TREATMENT OF DATA}

Analysis of variance was initially performed on all data sets to determine if observed differences in growth scores were significant or random. The analysis of variance (ANOVA) is a measure of differences among the groups. If there are no real differences among the groups, the value of the F-statistic (the ratio of the mean square between groups to the mean square within groups) should be close to 1.0. If the F-statistic is larger than the appropriate critical value, which is determined from published statistical table and the degrees of freedom, then it is likely that 
these differences are statistically significant (Downing and Clark, 1989. Zar, 1984). The ANOVA is a more valid test than the $t$-Test when $n$ is small. This test should be performed before the Student's $t$-Test. to insure that a statistically valid difference exists (Zar, 1984, Wallenstein et al., 1980). Because the sample size used for this investigation was at times as small as $\mathrm{n}=3$, it was prudent to first calculate an ANOVA and then a $\mathrm{t}$-Test, rather than a $t$-Test alone. When the sample size is small, a $t$-Test by itself is at risk of declaring that at least one significant difference exists. when, in fact. none may exist (Wallenstein et al., 1980).

Zar (1984) states that biostatisticians often specify that a probability of $5 \%$ or less is commonly used as the criterion for the rejection of the null hypothesis. This is why the significance level of $5 \%$ was chosen for analyzing the results.

If the ANOVA indicated a significant variance in a data set, the Student's $t$-Test is performed. This is a two tailed test in which the null hypothesis is either confirmed (the t-statistic is between the critical values) or rejected and the alternate hypothesis is accepted (the $t$-statistic is either below or above the critical values). These critical values are determined from published statistical tables and from the degrees of freedom of each data set (Downing and Clark. 1989. Zar. 1984). The same levels of significance were used in the evaluation of the Student's $t$-Test as for the ANOVA. 
CHAPTER III

\section{RESULTS}

The data from the growth promoter, cell division factor, and growth inhibitor experiments are discussed in the following section. The ANOVA for these results is significant at 0.05. Reported growth responses and values in the following tables (marked with an asterisk) are significant at 0.05 using a paired Student's t-Test.

\section{GROWTH PROMOTERS}

Figure 12 shows the response in growth at different concentrations of Gibberellic Acid (GA3). A maximal growth response (optimum) is observed in this study at the concentration of $0.04 \mathrm{mg} / 1(0.11 \mu \mathrm{M})$, beyond which further increases in GA3 concentrations (superoptimum) show a decrease in growth. A 260\% -193\% increase in growth was observed in the concentration range of $0.04 \mathrm{mg} / 1(0.11 \mu \mathrm{M})-4.0 \mathrm{mg} / 1(11 \mu \mathrm{M})$. Variation in $\mathrm{pH}$ is minimal and not likely to be responsible for this observed increase in growth. See Table II for a brief data summary.

Observations on morphology indicate no change in cell size or the presence of any gross aberrations in the chloroplasts. Random production of zygotes is noted in all treatments. 


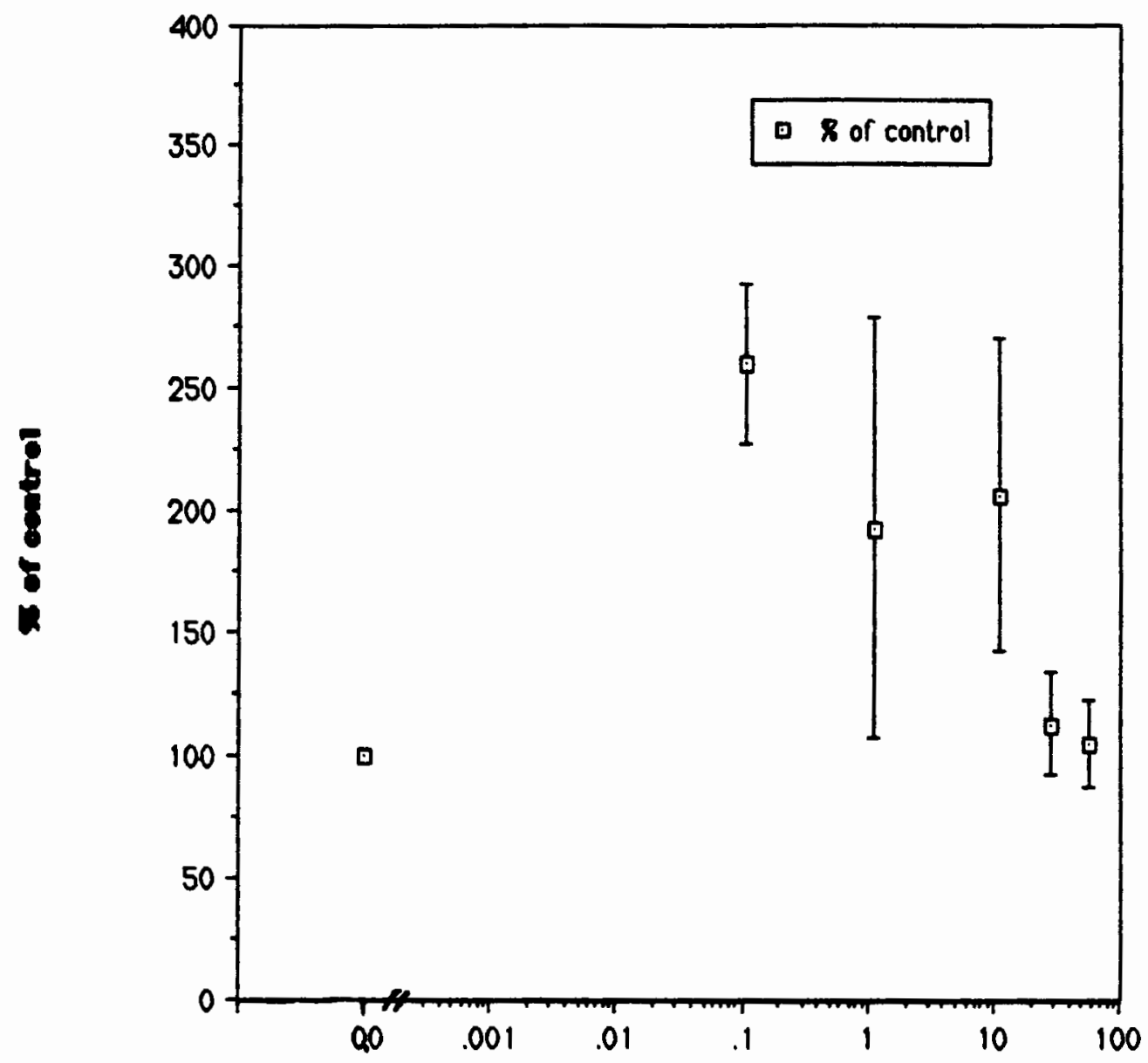

log conc. 6A

Eigure 12 * control versus $G A$ concentrations. Data demonstrates the growth effect of increasing $G A$ concentrations. Error bars represent the standard deviation. $n-6$. 


\section{TABLE II}

\section{SUMMARY OF THE EFFECTS OF GA, NAA, AND BAP ON GROWTH}

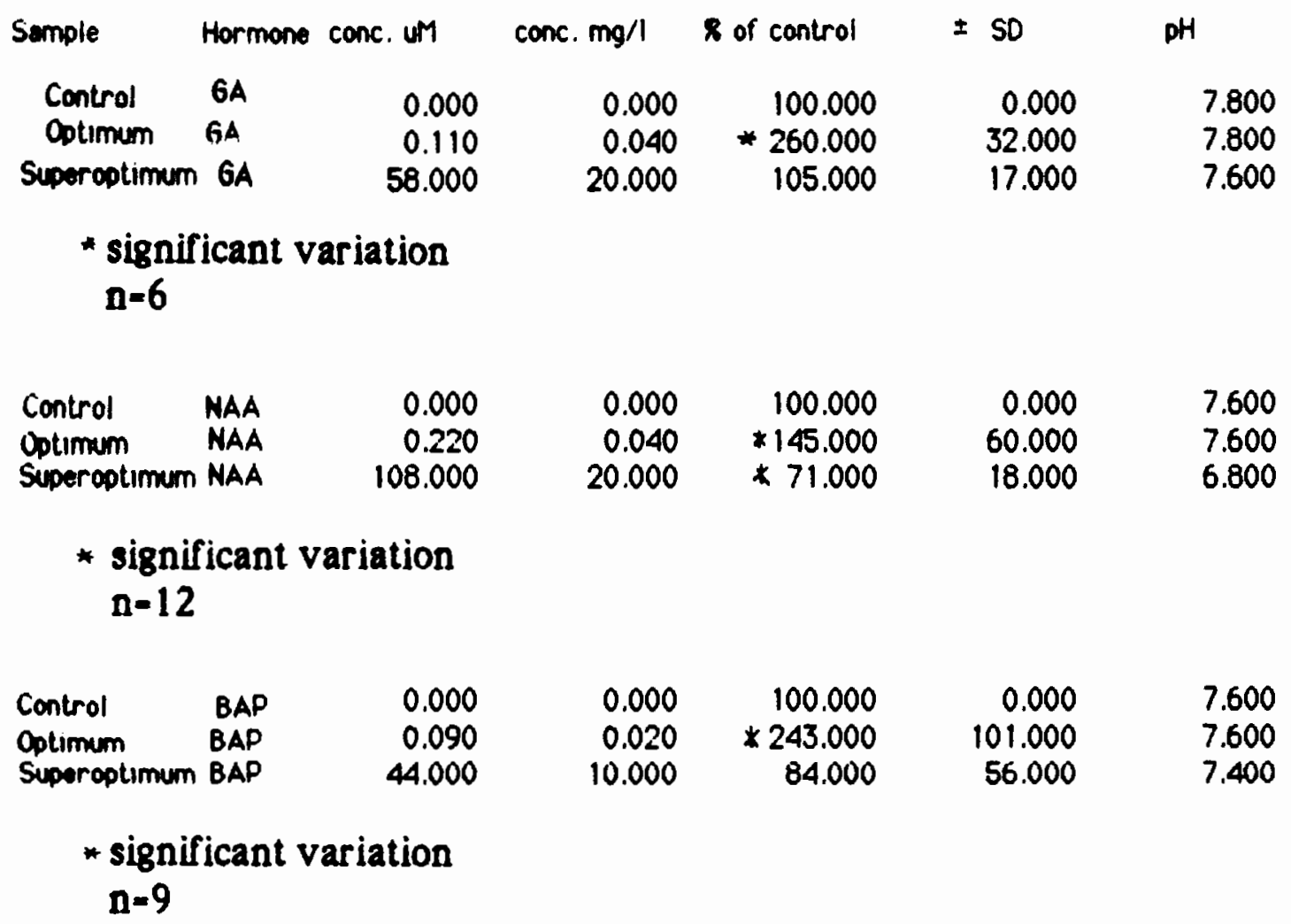


Figure 13 shows the response in growth at different concentrations of Napthalene Acetic Acid (NAA). A maximal growth response (optimum) to NAA occurred at the concentration of $0.04 \mathrm{mg} / 1(0.22 \mu \mathrm{M})$, beyond which further increases in NAA concentrations (superoptimum) eventually become inhibitive to growth.

NAA had a promotive effect at $0.04 \mathrm{mg} / \mathrm{l}(0.22 \mu \mathrm{M})$ which was $145 \%$ of the controls, and an inhibitive effect was noted at $10 \mathrm{mg} / 1(54 \mu \mathrm{M})$ and 20 $\mathrm{mg} / \mathrm{l}(108 \mu \mathrm{M})$ which was $69 \%$ and $71 \%$ of the controls. This inhibition corresponded to a slightly lower $\mathrm{pH}$ in the above mentioned treatments. See Table II for a brief data summary.

As is also observed in the GA3 treatments, observations of morphology indicated no change in cell size or the presence of any gross aberrations in the chloroplasts. Random production of zygotes was noted in all treatments.

\section{CELL DIVISION FACTORS}

Figure 14 shows the response in growth at different concentrations of Benzlaminopurine (BAP). When concentrations of BAP increase there is a range where optimal growth occurs, beyond which further increases in BAP concentration show a decrease in growth to the level of the controls.

A 243\% - 203\% increase in growth was observed in the concentration range of $0.02 \mathrm{mg} / 1(0.09 \mu \mathrm{M})-2 \mathrm{mg} / 1(9 \mu \mathrm{M})$. Variation in $\mathrm{pH}$ was minimal and not likely to have caused this observed increase in growth. See Table II shows a brief data summary.

Like the GA3 and NAA treatments, observations on morphology 


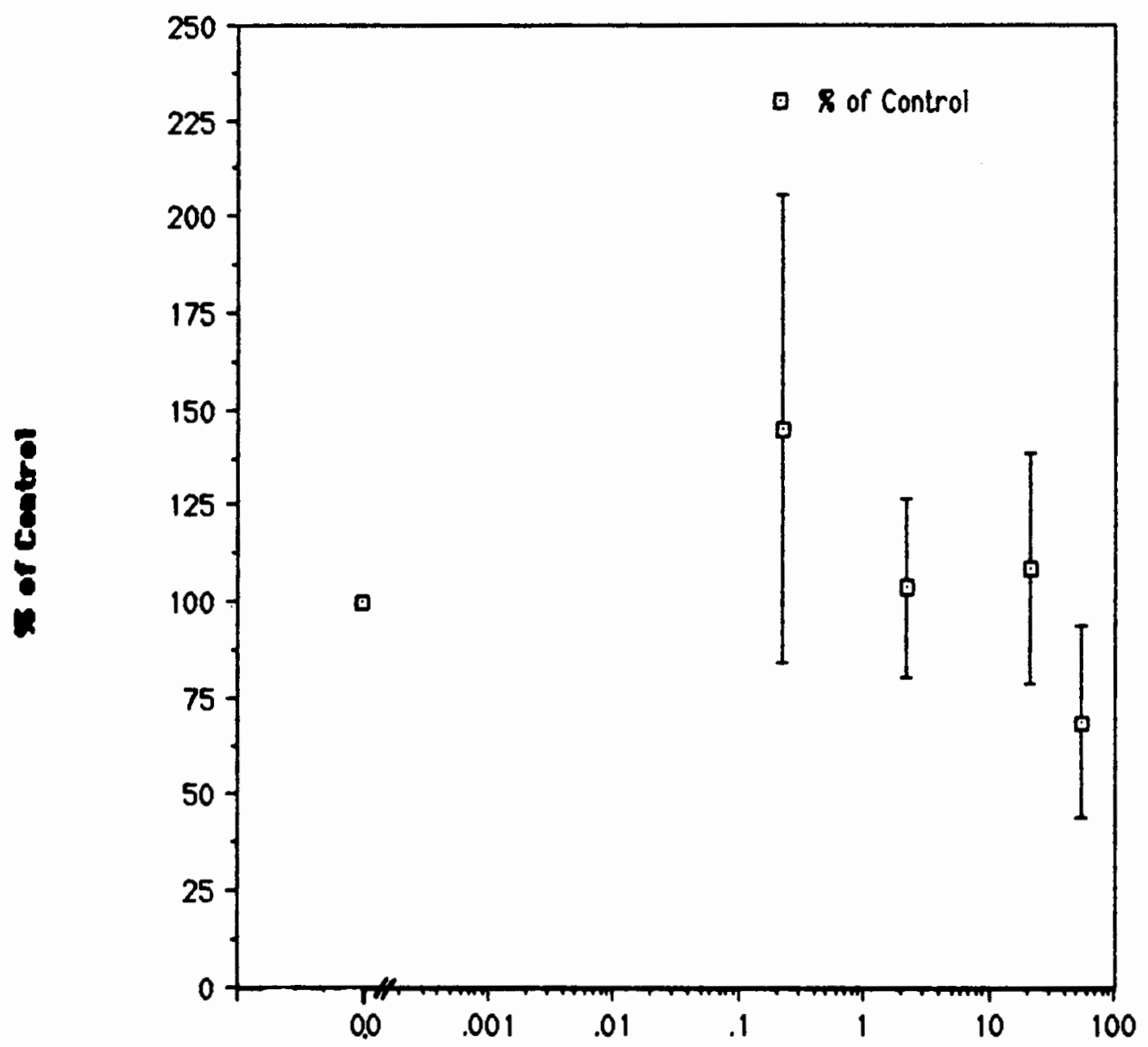

log conc. MAA

Eigure 13. * control versus NAA concentrations. Data demonstrates the growth effect of increasing NAA concentrations. Error bars represent the standard deviation. n-12. 


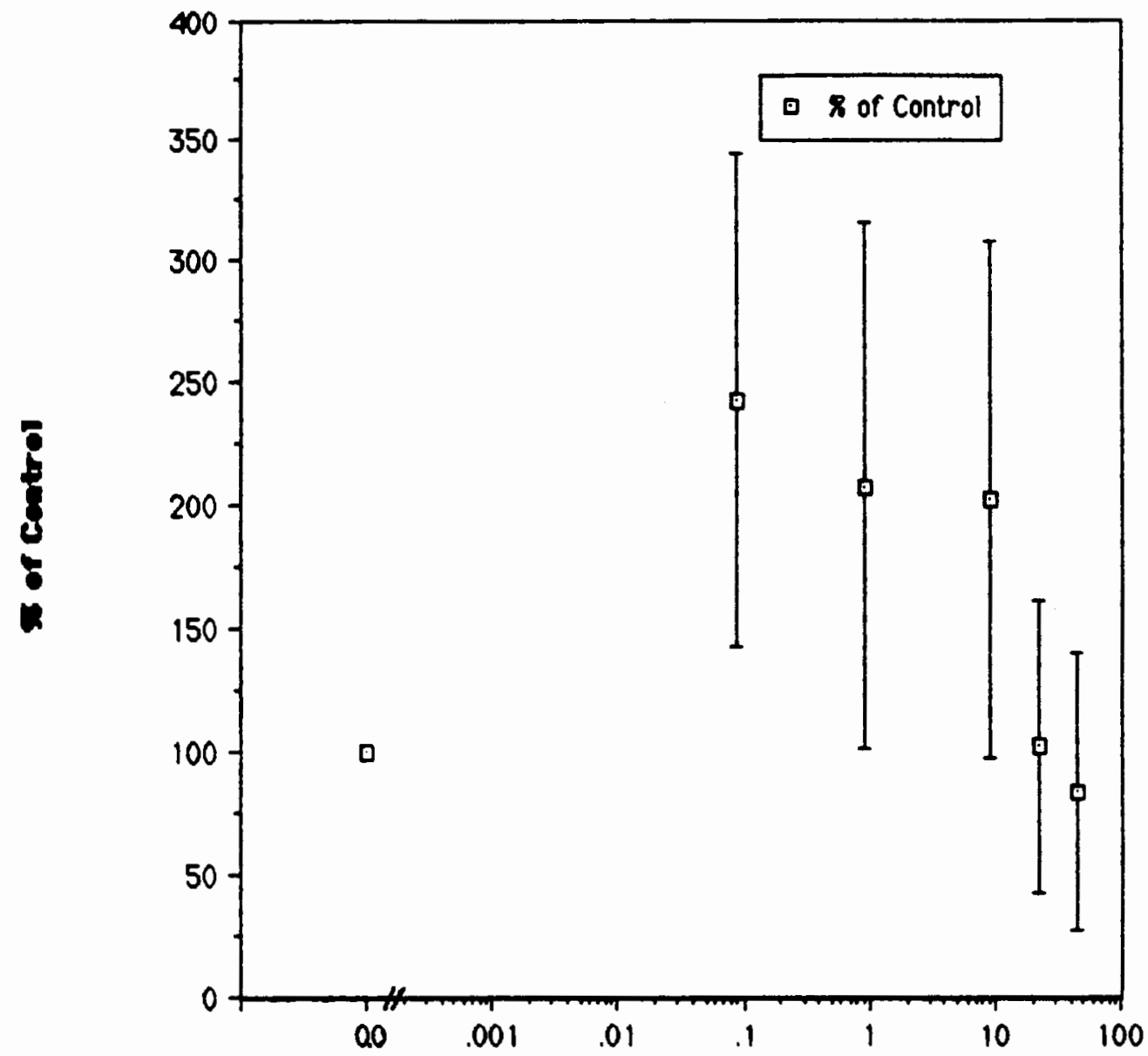

log conc. BAP

Eigure 14. * control versus BAP concentrations. Data demonstrates the growth effect of increasing BAP concentrations. Error bars represent the standard deviation. $\mathrm{n}=9$. 
indicated no change in cell size. However, chloroplasts appeared pale in the $10 \mathrm{mg} / 1$ (44) BAP treatment. Random production of zygotes was noted in all treatments.

\section{GROWTH INHIBITORS}

Figure 15 shows the response in growth at different concentrations of Abscisic Acid ( $A B A)$. At all concentrations of $A B A$ above the control, there is inhibition of growth which appears to remain constant as the ABA concentrations increase. This inhibitive effect of ABA restricted growth to $52 \%-66 \%$ of the controls. Table III shows the accumulated data for ABA.

As observed in the other growth regulator treatments, no change was observed in cell morphology. Random production of zygotes was noted in all treatments of $A B A$..

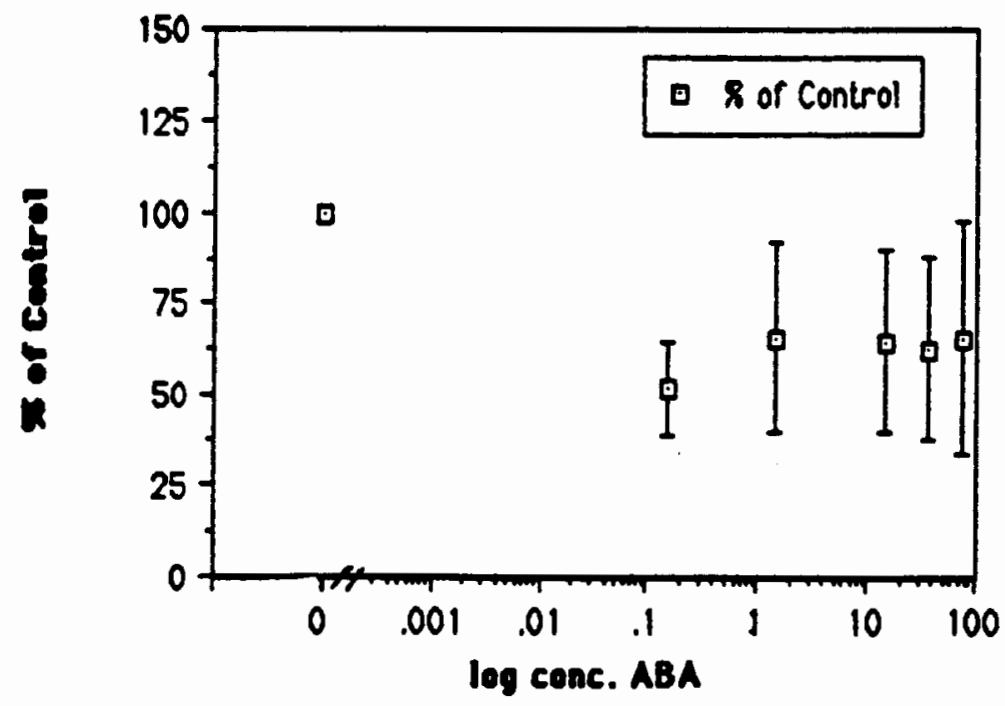

Eigure 15. \% control versus $A B A$ concentrations. Data demonstrates the growth effect of increasing ABA concentrations. Error bars represent the standard deviation. n-9. 


\section{TABLE V}

\section{THE EFFECT OF ABA ON GROWTH}

$\begin{array}{rrrrrr}\text { log conc. ABA conc ABA mg/l } & \text { R of Control } & \text { I s.d } & \text { t-Test value } & \text { PH } \\ 0.000 & 0.000 & 100.000 & - & - & 7.800 \\ 0.150 & 0.040 & * 52.000 & \pm 13.000 & -11.080 & 7.800 \\ 1.500 & 0.400 & * 66.000 & \pm 26.000 & -3.923 & 7.800 \\ 15.000 & 4.000 & \$ 65.000 & \pm 25.000 & -4.200 & 7.600 \\ 38.000 & 10.000 & \$ 63.000 & \pm 25.000 & -4.440 & 7.400 \\ 76.000 & 20.000 & \$ 66.000 & \pm 32.000 & -3.188 & 7.200\end{array}$

ANOYA F-4.569; 0-9

Pr(F<2.410)-0.95

Student's t-Test

$\operatorname{Pr}(-2.306, X(2.306)=0.95$

- statistically sigaificant 
CHAPTER IV

\section{DISCUSSION}

It was mentioned earlier that growth is defined in this study as an increase in cell number. In both the growth promoters and cell division factors, there were concentrations where growth increased to a maximum and beyond which, superoptimum concentrations resulted in a decrease in growth (Table II). Abscisic acid used at all concentrations resulted in growth inhibition. These results are similar to those found by other workers as explained below.

The response curve to increasing GA3 concentrations was similar to Adair and Millers' (1982) findings in the diatom Cyclotella cryptica The optimal response in Adair and Millers' (1982) work was at the concentration of $0.02 \mathrm{mg} / \mathrm{l}$, which was followed by suboptimal growth at increasing concentrations. The optimal response in this study was 0.04 $\mathrm{mg} / 1(0.11 \mu \mathrm{M})$, with suboptimal growth occurring at increasing concentrations. Due to the small $\mathrm{n}$ and the large standard deviation these results may be insignificant.

Wood and Berliner (1979) found gibberellic acid to have no effect on growth in the desmid Micrasterjas thomasiana at concentrations of $1 \mathrm{mg} / 1$. $2 \mathrm{mg} / \mathrm{l}$, and $4 \mathrm{mg} / \mathrm{l}$. A possible reason for this differing response may be that the concentrations Wood and Berliner tested were out of their organism's range of optimal growth response. At concentrations above 5 
$\mathrm{mg} / \mathrm{l}$ with a pH below 5.3 Wood and Berliner (1979) found gibberellic acid to be lethal for their organism. As explained in the materials and methods section a similar lack of response was noted when ethanol was used as a solvent for GA3; but, preliminary studies indicated that protocol was not suitable for use in this study.

Morphology wis not affected by increasing GA3 concentrations in Closterium moniliferun, in the Cyclotella studied by Adair and Miller (1982), or in the Euglena studied by Bralczyk et al. (1978). Zygospore production was also not affected in Closterium moniliferum by GA3 addition to growth media.

In this study the growth response by Closterium moniliferum indicates the possible utilization of $\mathrm{GA} 3$ if ine regulation of cell division. The demonstration of a function of GA? in an endogenous specific control mechanism in Closterium moniliferum a ould be necessary to prove this utilization.

The shape of the response curve to increasing NAA concentrations was similar to the response Wood and Berliner ( 1979$)$ found with increasing IAA concentration. The optimal response in this study was at a concentration $0.04 \mathrm{mg} / 1(0.22 \mu \mathrm{M})$ with suboptinial growth and eventual inhibition occurring at increasing concentrations. It is possible that these results may be insignificant, because of a small $\mathrm{n}$ and large standard deviations. However, Wood and Berliner (1979) found a similar response with maximal growth occuring at $0.4 \mathrm{mg} / \mathrm{l}$ of $\mathrm{IAA}$ in the desmid Micrasterias, followed by suboptimal growth and eventual intibition at increasing concentrations. This maximum growth response fc'lowed by suboptimal growth is typically seen in vascular plants (Salisbury arid Ross. 
1985).

The inhibition observed in this study at $10 \mathrm{mg} / \mathrm{l}(54 \mu \mathrm{M})$ and $20 \mathrm{mg} / 1$ $(108 \mu \mathrm{M})$ is not likely due to the lower $\mathrm{pH}$ occurring in these treatments, because the $\mathrm{pH}$ fell well within the normal physiological tolerances of the organism.

Morphology was not effected by increasing NAA concentrations in Closterium moniliferum, or by increasing IAA concentrations in the desmid Micrasterias (Wood and Berliner. 1979), or in the desmid Cosmarium (Berliner, 1981).

Zygospore production remained random in the treatments tested in this study. In other desmid work. Lippert (1973) found no difference in zygospore production when when concentrations of $0.001 \mathrm{mg} / 1-0.1 \mathrm{mg} / 1$ of IAA and NAA were added mating cultures of Closterium moniliferum.

Wood and Berliner (1979) and Berliner (1981) found the increased growth in the desmids they studied to be due to a shortening of the lag phase--the time between successive cell divisions. A shortening of the lag phase may account for the increased growth observed in this study. However, more frequent observations in a repeat study on the effects of NAA on Closterium moniliferum would have to be made to demonstrate a similar shortening of the lag phase of growth.

It is possible that NAA is utilized by Closterium as a growth regulator. because NAA promotes growth at specific concentrations and inhibits growth at subsequent (higher) concentrations. However, demonstration of a function of NAA in an endogenous specific control mechanism would be necessary to prove this utilization.

Different organic acids were tested to see if the effect on growth by the 
growth promoters and $A B A$, was due to acid dissociation or non-dissociation under the experimental conditions. The growth regulators GA3. NAA, and $\mathrm{ABA}$ are small molecular weight acids whose acidic character was tested using organic acids of a similar size. No significant increase in growth was noted from any of the acids tested. Both acetic acid and butyric acid were found to be lethal at concentrations greater than $75 \mu \mathrm{M}$.

The shape of the response curve to increasing BAP concentration was similar to that observed by Berliner (1981) when she studied the effects of kinetin on Cosmarium. In this study an optimal growth response to BAP occurred at the concentration of $0.02 \mathrm{mg} / 1(0.09 \mu \mathrm{M})$, with suboptimal growth occurring at increasing concentrations. If this curve was extrapolated further an inhibitive effect may be demonstrated which could correspond to Berliner's (1981) findings of optimal growth followed by suboptimal growth and eventual inhibition with increasing concentrations of kinetin. However, due to the small $\mathrm{n}$ and the large standard deviation in this study the significance of this results must be considered with caution.

Preliminary work demonstrated a shortening of the lag phase of growth in the concentration range of $0.02 \mathrm{mg} / 1(0.09 \mu \mathrm{M})-2 \mathrm{mg} / \mathrm{l}(9 \mu \mathrm{M}) \mathrm{BAP}$. This corresponds to the BAP treatments that had a significant promotive effect on growth. Wood and Berliner (1979). Berliner (1981), and Vance (1987) also observed this shortening of the lag phase when kinetin was added to the growth media organisms they studied. Consequently the observed increase in the growth of Closterium moniliferum was due directly to an increase in the rate of cell division.

Morphology was not affected by kinetin in the work reported by Berliner (1981). Vance (1987), and Wood and Berliner (1979). In this 
study cell size was not affected by BAP; however, the chloroplasts were notably pale at concentrations of $10 \mathrm{mg} / 1(44 \mu \mathrm{M})$. In other work (not shown) similar findings were made at the same concentration of BAP along with the observation of cell and zygospore lysing.

Zygospore formation remained random among treatments in this study. Lippert (1973) had observed an increase in zygospore production when kinetin was added to Closterium moniliferum, however, he did not count the total number of cells at the end of his experiment (Lippert. personal communication). It is hypothesized that the percent of zygotes formed remained the same the same in Lippert's (1973) study, and that it was an increase in total cell numbers in the kinetin treatments that resulted in a larger number of zygotes formed. This could easily have occurred from a shortening of the lag phase. In this study, the largest increase in growth was noted at $0.02 \mathrm{mg} / 1(0.09 \mu \mathrm{M})$, which corresponds nicely to the largest response of zygospore production in Lippert's (1973) experiment. The observed response of BAP at $0.2 \mathrm{mg} / 1(0.9 \mu \mathrm{M})$ and at $2.0 \mathrm{mg} / 1(9 \mu \mathrm{M})$ could also correspond to Lippert's (1973) results, assuming that the total cell number influenced his zygospore production.

This study demonstrates the possible utilization of BAP as a cell division factor by Closterium moniliferum, due to its effect on increasing the rate of cell division. However demonstration of a function of BAP in an endogenous specific control mechanism would be necessary to prove this utilization.

The addition of $A B A$ to the culture media resulted in significant inhibition of growth at all concentrations tested. This demonstrates the possible utilization of $\mathrm{ABA}$ by Closterium moniliferum as a growth 
inhibitor. However, demonstration of a function for $A B A$ in an endogenous specific control mechanism would be necessary to prove this utilization by Closterium moniliferum.

Cellular morphology was not effected by the increasing concentrations of $\mathrm{ABA}$ in this study, and zygospore production remained random between all treatments. 
CHAPTER V

\section{SUMMARY}

Physiologic responses to $\mathrm{GA}, \mathrm{NAA}, \mathrm{BAP}$ and $\mathrm{ABA}$ suggest that Closterium moniliferum utilizes these compounds or their decomposition products. This makes it more likely that they may possibly produce similar compounds or that they could have evolved synergistically with a closely associated organism that produced plant growth factors, such as a bacterium or as an epiphyte on some other plant (Chapman and Vance, 1976).

Synergistic effects of plant growth factors were not studied because earlier work has not demonstrated any effect on growth with different combinations of auxins, cytokinins, and gibberellins (Berliner, 1981, Vance, 1987). It is unlikely a response would be observed in a unicellular alga since these synergistic effects in vascular plants are involved in tissue differentiation.

The growth promoters NAA and GA increased growth and did not effect the cellular morphology of Closterium moniliferum. The cell division factors BAP increased growth by decreasing the lag phase and only effected morphology at the concentration of $10 \mathrm{mg} / 1(44 \mu \mathrm{M})$. Abscisic acid was inhibitory to growth at all concentrations tested and had no visible effect on morphology.

Very little is known about how the various classes of plant growth 
regulators work as their site of action and production are generally nonspecific (Salisbury and Ross, 1983). It is hoped that the work represented here offers a model that could be used in future studies to investigate specific sites of hormone action at a cellular level. The following work needs to be done if the organism used here is to be used in the future:1. Hormone antagonists need to be applied to see if they interfere with the physiological response. 2. If hormone antagonists will block hormone action then long term experiments should be completed to assay the total cell constituents--proteins, chlorophylls, etc.--when cells are grown under different hor mone regime. 3. This would give baseline data and allow the investigator to determine gross differences between protein levels and other cell constituents. 4 . If differences are found then the cell machinery responsible Yor those specific protèns could be investıgated in greater detail. 5. Eventually radioactive labeled growth factors would be needed to attempt to track receptor proteins. The difficulties in this type of study involve the designing of appropriate extraction techniques and assays to determine binding sites. 


\section{REFERENCES}

Adair, O. and Miller, M. 1982. "Growth Responses of the Diatom, Cyclotella cryptica (Bacillariophyceae), to Gibberellic Acid," J. Phycol. 18:587589.

Arditti. J. and Dunn, A. 1969. Experimental Plant Physiology: Experiments in Cellular and Plant Physiology. Holt Rinehart, and Winston , Inc., publishers, New York, 264.

Berliner, Martha, 1981. "Hormone Effects on Cosmarium botrytia Cell Division." Cytobios. 30:89-99.

Bralczyk, P., Wielgat, B., Wasilewska-Dabrowska, L.,Kleczkowski, B. 1978. "Growth Accelerating Response of Euglena gracilis $z$.to Gibberellic Acid. Plant Science Letters 12:265-271.

Brook, A. J., 1981. Botanical Monographs: Volume 16: The Biology of Desmids. University of California Press, Berkeley, Calif.

Buggeln, R. 1976. "Auxin. an Endogenous regulator of growth in Algae?" J. Phycol. 12:355-358.

Chapman, R. and Vance, B. 1976. "Ethephon (2-Chloroethylphosphoric Acid) Effects on Scenedesmus quadricauda (Chlorophyceae)," J. Phycol. 12:146-149.

Darley, W. M. 1982. Algal Biology: a PhysiologicalApproach. Blackwell Scientific Publications, Ozford.

Davies, Peter 1990 (In Press). "Gibberellins"In Plant Physiology. Benjamin/Cummings Redwood. CA.

Downing, D. and Clark, J. 1989. Statistics. The Easy Way. Barron's Educational Series, Inc., New York.

Droop, M.R. 1974. "Heterotrophy of Carbon." In Stewart, W. D. P. [Ed.] Algal Physiology and Biochemistry. Blackwell Scientific, Orford 
Fosket, Donald 1990 (In Press). "Cytokinins"In Plant Physiology. Benjamin/Cummings Redwood, CA.

Goodwin, T. W. and Mercer, E. I., 1985. Introduction to Plant Biochemistry. Pergamon Press, Oxford. 567-626.

Gorham, J.. 1977. "Lunularic Acid and Related Compounds in Liverworts. Algae and Hydrangea." Phytochemistry. 16:249-253.

Grotbeck, L. and Vance, D. 1972. "Endogenous Levels of Indole-3-Acetic Acid in Synchronous Cultures of Chlorella pyrenoidosa" J. Phycol. 8:272-275.

Hamada, J., 1978. "Studies on Several Environmental Factors for Zygote Formation and Germination in Closterium ehrenbergii" Bot. Mag Tokyo. 91:173-180.

Hellebust, J. 1974. "Extracellular Products." In Stewart, W. D. P. [Ed.l Algal Bhysiology and Biochemistry. Black well Scientific, Oxford. 838-863.

Hussain, A. and Boney, A. D. 1973. "Hydrophyllic Growth Inhibitors From Laminaria and Ascophyllum. New Phytol. 72:403-410.

Jennings, R. C. 1969. "Gibberellin Antagonism by Material From a Brown Alga." New Phytol. 68:683-688.

Kutacek, M. 1985. "Auxin Biosynthesis and its Regulation on the Molecular Level." Biologia Plantarum. 27(2-3):145-153.

Lee, R. E. 1980. Phycology. Cambridge University Press, Cambridge.

Lippert, B. E. 1973. "Some Factors Affection Conjugation In Closterium (Desmidiaceae)." Beih. Nova Hedwigia 42:171-177.

Lippert, B. E. 1967. "Sexual Reproduction in Closterium moniliferum and Closterium ehreabergit." J. Phycol. 3:182-198.

Lippert, B. E. Personal communication.

McGaw, B. A. and Horgan R. 1985. "Cytokinin Metabolism and the Control of Cytokinin Activity." Biologia Plantarum 27(2-3):180-187. 
Pickett-Heaps, J. 1975. Evolution and Cell Morohology: Green Algae Structure. Reproduction and Evolution in Selected Genera. Sinhaver Associates, Inc., Sunderland, Mass.

Pharis, R. P. and Reid, D. M. [Eds.] 1985. Hormonal Regulation of Development III Role of Environmental Factors. Springer-Verlag, Berlin.

Prescott, G. W. 1968. The Algae: A Review. Houghton Mifflin Company, Boston, Mass.

Prescott, G. W. 1978. How to know the Eresh Water Algae. Wm. C. Brown Company, Dubuque, Iowa.

Prikryl. Z.. Vancura, V and Wurst, M.1985. "Auxin Formation by Rhizosphere Bacteria as a Factor of Root Growth." Biologia Plantarum 27(2-3):159-163.

Provasoli, L. and Carlucci, A. F. 1974. "Vitamins and Growth Regulators." In Stewart. W. D. P. [Ed.] Algal Physiology and Biochemistcy. 741-87.

Pryce, R. J. 1972 "The occurrence of Lunularic and Abscisic Acids in Plants." Phytochemistry. 11:1759-1761.

Pryce, R. J. 1971. "Biosynthesis of Lunularic Acid--A Dihydrostilbene Endogenous Growth Inhibitor of Liverworts." Phytochemistry. 10:2679-2685.

Pryce. R. J. 1971. "Lunularic Acid, a Common Endogenous Growth Inhibitor of Liverworts." Planta 97:354-357.

Radley, M. 1961. "Gibberellin-like Substances in Plants." Nature. 1919:684-685.

Raub, M., Cardellina, J. and Schwede, J. 1987. "The Green Algal Pigment, Caulerpin, as a Growth Regulator." Phytochemistry. 26(3):619-620.

Rayle. D. L. and Cleland. R. E. 1977. "Control of Plant Cell enlargement by Hydrogen Ions." Curr. Top. Dev. Biol 34:187-213.

Rueter, J. Personal communication. 
Round, F. E. 1965. The Biology of the Algae. St. Martin's Press, New York.

Salisbury, F. B. and Ross, C. W. 1985. Plant Physiology. Wadsworth Publishing Company, Belmont. 290-349.

Scott. Tom [Ed.]. 1984. Hormonal Regulation of Development IL the Functions of Hormones from the Level of the Cell to the Whole Plant. Springer-Verlag, Berlin. 57-61.

Shapiro, L., Haugen, E., Keller, M., Bidigare, R., Campbell, L., and Guillard, R. 1989. J. Phycol. 25:794-797.

Sigma 1989. "Gibberellic Acid "Plant Cell Culture Reagents Product Insert.

Soeder, C. and Stengel, E. 1974. "Physico-chemical Factors Affecting Metabolism and Growth Rate." In Stewart, W. D. P. [Ed.] Algal

Bhysiology and Biochemistry. Blackwell Scientific, Orford. 714-40.

Stein, Janet [Ed.] 1973. Handbook of Phycological Methods Culture Methods and Growth Measurements. Cambridge University Press, Cambridge.

Stout, Richard 1990 (In Press). "Auxins: Growth and Tropisms" In Plant. Physiology. Benjamin/Cummings Redwood, CA.

Taylor, I. and Wilkinson, A. 1977. "The occurrence of Gibberellins and Gibberellin-Like Substances in Algae." Phycologia. 16:37-42.

Theologis, A. 1985. "Rapid Gene Regulation by Auxin." Ann. Rev. Plant Physiol. 37:407-438.

Valio, I. G. M.. Burden. R. S. and Swabe. W. W. 1969. "New Natural Growth Inhibitor in the Liverwort, Lunufaria cruciata. (L.) Dum." Nature. 223:1176-1178.

Vance, D. 1987. "Phytohormone Effects on Cell Division in Chlorella pyrenodoidosa Cich (TX-7-11-05) (Chlorellaceae)." J. Plant Growzh Regul. 5:169-173.

Wallenstein. S., Zucker, C. and Fleiss, J. 1980. "Some Statistical Methods Useful in Circulation Research." Circulation Research. 47:1-9. 
Wood, N. and Berliner, M. 1979. "Effects of Indoleacetic Acid on the Desmid, Micrasterias thomasiana.". Plant Science Letters. 16:285-289.

Zar, J. H. 1984. Biostatistical Analysis 2nd Edition. Prentice Hall, Inc., Englewood Cliffs, New, Jersey.

Zhang, W., Yamane, H.. Takahashi. N.. Chapman. D. and Phinney, B. 1989. "Identification of a Cytokinin in the Green Alga, Chara globularis:" Phytochemistry. 28:337-338. 